\title{
TÓPICOS DE GEOCIÊNCIAS PARA O DESENVOLVIMENTO SUSTENTÁVEL: AS REGIÕES LITORÂNEAS
}

\author{
Professor Doutor Kenitiro Suguio \\ Departamento de Geologia Sedimentar e Ambiental \\ Universidade de São Paulo
}




\section{ÍNDICE}

03

03

03

04

07

09

10

10

11

11

11

11

13

13

13

14

16

19

19

20

20

21

22

24

25

26

27

27

\section{INTRODUÇÃO}

\section{CLASSIFICAÇÃO DE REGIÕES LITORÂNEAS}

I.1. Generalidades

I.2. Alguns exemplos de classificações

I.3. Classificação da região litorânea do Brasil

I.3.1 O litoral amazônico ou equatorial

I.3.2. O litoral nordestino

I.3.3. O litoral oriental

I.3.4. O litoral sudeste ou das escarpas cristalinas

I.3.5. O litoral meridional ou subtropical

II. AS PLANÍCIES COSTEIRAS OU BAIXADAS LITORÂNEAS

II.1. O que são planícies costeiras?

II.2. Como e quando se formaram as planícies costeiras?

II.2.1. Causas paleoclimáticas

II.2.2. Reconstrução dos níveis do mar pretéritos

II.2.2.1. Evidências de níveis relativos do mar abaixo do atual

II.2.2.2. Evidências de níveis relativos do mar acima do atual

II.2.3. Antigos níveis do mar, acima do atual, registrados na costa brasileira

II.2.3.1. Registros de níveis do mar anteriores a 123.000 anos AP

II.2.3.2. Registros de níveis do mar mais altos que o atual de 123.000 anos AP

II.2.3.3. Registros de níveis do mar mais alto que o atual do Holoceno

II.2.4. Curvas de variação dos níveis relativos do mar nos últimos 7.000 anos

II.2.5. Algumas conseqüências das flutuações dos níveis relativos do mar na sedimentação costeira

II.2.6. Papel do transporte longitudinal de areia na sedimentação costeira

II.2.6.1. O bloqueio do transporte longitudinal por uma desembocadura fluvial

II.2.6.2. Padrões de sistemas de ondulações ao longo da costa central brasileira

II.2.7. Principais estágios de construção das planícies da costa central brasileira

II.2.7.1. Modelo geral

II.2.7.2. Casos especiais de planícies costeiras situadas nas desembocaduras de grandes rios

II.2.7.3. Casos de planícies costeiras brasileiras ainda pouco estudadas

III. AS REGIÕES LITORÂNEAS E O DESENVOLVIMENTO SUSTENTÁVEL

III.1. Generalidades

III.2. Situação das regiões litorâneas brasileiras em relação aos "perigos naturais" e à conservação de ecossistemas

III.3. Erosão acelerada de falésias marinhas

III.4. Erosão acelerada de praias

III.5. Conservação de ecossistemas costeiros

\section{AGRADECIMENTOS}

REFERÊNCIAS BIBLIOGRÁFICAS

BIBLIOGRAFIA ADICIONAL PARA EVENTUAL CONSULTA 


\section{INTRODUÇÃO}

As regiões litorâneas (ou costeiras) constituem as faixas limítrofes entre os continentes (terras emersas) e os oceanos (terras submersas), representando uma das áreas de mais intenso intercâmbio de energia e matéria do Sistema Terra. Como tal, essas regiões mantém-se, em geral, sob condições de equilibrio dinâmico e não de equilíbrio estático. Destarte, formam áreas muito suscetíveis a mudanças, podendo ser afetadas em diversas escalas temporais e espaciais, sofrendo importantes transformações, que podem ou não ser reversíveis.

Além disso, as regiões litorâneas comportam um dos mais ricos e mais importantes conjuntos de ecossistemas naturais, de cuja preservação dependem os ciclos vitais de inúmeros animais e vegetais. Dentre alguns desses ecossistemas podem ser mencionados os seguintes: praias, manguezais e recifes de corais (ACIESP, 1987 e 1990; ACIESP/ABC, 1994 e 1998).

Por outro lado, essas regiões estão sendo invadidas, em escala mundial, pelo rápido incremento populacional, que constitui uma das conseqüências diretas do desenvolvimento econômico. Embora as proporções sejam variáveis em diferentes países estima-se que, hoje em dia, cerca de $2 / 3$ da população da Terra do total de 6 bilhões, ou seja, aproximadamente 4 bilhões de habitantes vivam ao longo da costa. Embora no Brasil esta proporção seja bem menor, quatro das áreas metropolitanas mais populosas do país estão localizadas na costa. Segundo Souza \& Suguio (1996), cerca de 3,9\% da população paulista, correspondente a 1.300.000 habitantes, vivem na área. Esta população é, no mínimo, duplicada durante as férias escolares ou feriados prolongados, principalmente na área de Santos. Abrangendo cerca de 50\% dos municípios litorâneos paulistas (Bertioga, Guarujá, São Vicente, Praia Grande, Itanhaém e Peruíbe, além de Santos) a assim denominada Baixada Santista comporta o distrito industrial e a conseqüente concentração de habitantes mais importante do país, colocando-a em situação de adensamento populacional e de exploração de recursos naturais, inclusive ambiental, praticamente insustentável. Inúmeros conflitos, gerados em função da ocupação desordenada do espaço físico terrestre das regiões litorâneas, poderiam ser minimizados e, em certos casos até mesmo eliminados, se os principais fatores geológicos e geomorfológicos que controlam ou afetam a área estivessem melhor equacionados. Esses fatores, segundo Peck \& Williams (1992), são: mudanças eustáticas do nível do mar, suprimento (alimentação) de areia à região litorânea, soerguimento isostático, movimentos tectônicos regionais, impactos de tempestades, processos costeiros (ondas, marés, correntes litorâneas e ventos) e atividades humanas (dragagem, mineração, construção de barragens, estruturas de proteção costeira, extração de fluidos como água, petróleo e gás).

No entanto, Suguio (1999) como editor-convidado de "Geociências e a comemoração do 500ํaำ aniversário da descoberta do Brasil" lamenta que, em termos de política governamental mais séria e efetiva de manejo e uso sustentável dos recursos naturais (manguezais, recifes de corais e minérios), há muito poucas coisas a serem comemoradas. Antes, talvez, esta seja uma oportunidade para que os geocientistas brasileiros meditem conscienciosamente sobre estes problemas muito presentes que, sem a devida postura visando o desenvolvimento sustentável, podem comprometer seriamente a própria sobrevivência da humanidade.

Portanto, urge que as regiões litorâneas, como parte integrante muito importante do Sistema Terra, sejam mais seriamente estudadas como no Programa Internacional Geosfera-Biosfera (PIGB, 1990), na tentativa de quantificação dos processos físicos, químicos e biológicos atuantes para se estimar o nível do seu desenvolvimento sustentável. Entre as atividades do Projeto LOICZ (Interações Continente-Oceano na Zona Costeira), pertencente ao programa mencionado e em funcionamento, foram previstos os seguintes quatro aspectos principais: os efeitos das mudanças nos forçantes externos ou nas condições-limite sobre os fluxos costeiros, biogeomorfologia costeira e subida do nível do mar, fluxos de carbono e emissões de gases-traço e finalmente os impactos econômicos e sociais das mudanças globais sobre os sistemas costeiros. Desde a implementação deste projeto, no Brasil foram produzidas duas publicações contendo trabalhos de interesse para o LOICZ (Suguio et al., 1996, 1998).

\section{CLASSIFICAÇÃO DE REGIÕES LITORÂNEAS}

\section{I.1. Generalidades}

Acredita-se que, na introdução deste texto, tenha sido demonstrada a importância das regiões litorâneas, não somente como um profícuo campo de pesquisas acadêmicas, mas também pelo seu interesse como um dos mais importantes sítios de assentamentos de populações humanas, 
desde os tempos pré-históricos (por exemplo, na época do "Homem do sambaqui") até hoje.

Então, qual é o objetivo de uma classificação? Quais são os critérios geocientíficos mais comumente usados nas classificações?

Antes de mais nada, é necessário entender que as classificações têm normalmente um papel muito importante na sistematização dos conhecimentos, pois os dados adquiridos ao longo do tempo, em diferentes trechos do litoral, poderão ser melhor concatenados e, portanto, representados e interpretados com maior propriedade. Entretanto, além da classificação de regiões litorâneas com bases geocientíficas, que melhor traduzirão a evolução natural até atingir a situação presente, elas poderiam ser também classificadas de várias outras maneiras, cada uma delas visando finalidades específicas.

Por outro lado, mesmo os critérios geocientíficos podem assumir, no mínimo, duas características, isto é, alguns são essencialmente descritivos e outros são genéticos. O ideal seria, talvez, realizar uma classificação essencialmente genética, pois desta maneira, só a menção de algumas palavras-chave poderia conduzir à perfeita compreensão das suas origens. Entretanto, como nem sempre se consegue chegar à gênese, comumente são adotados critérios mistos, isto é, genéticos e descritivos.

\section{I.2. Alguns exemplos de classificações}

Durante muito tempo a proposta de Johnson (1919), baseada em critérios genéticos, foi amplamente utilizada (Tab. I). Ela depende do conhecimento da suposta história recente da região litorânea, sendo reconhecidas costas de submersão (continente em subsidência ou nível do mar em ascensão), costas de emersão (continente em soerguimento ou nível do mar em descensão), costas neutras (continente e nível do mar estáveis) e costas compostas (mistas).

Apesar de muito clara, nem sempre se consegue adotar adequadamente esta classificação, pois após o episódio glacial do Quaternário, o nível do mar esteve em ascensão em escala global. Por outro lado, são bastante numerosas as evidências de níveis do mar superiores ao atual correspondentes aos estádios interglaciais. Uma das costas neutras, de acordo com esta classificação são as costas de deltas que, às vezes constituem costas de submersão, como acontece no caso do Rio Mississippi (EUA) e outras vezes correspondem a áreas mais ou menos estáveis, como no delta do Rio Doce (Brasil). Entretanto, talvez o pior defeito desta classificação se refira ao uso de barreiras (chamadas de "barras de costa afora"), como principal critério de definição de costas de emersão. Hoje em dia sabese muito bem que as chamadas "ilhas-barreira" (barrier

Tab. I - Classificação de costas segundo D. W. Johnson (1919).

1. COSTAS DE SUBMERSÃO:

1.1 - Costa com "rias"... Baía de Dingle (SW da Irlanda)

1.2 - Costa com fiordes - Fiorde de Sogne (W da Noruega)

2. COSTAS DE EMERSÃO (com barras arenosas)... Mar Báltico

3. COSTAS NEUTRAS:

3.1 - Costa com deltas... Delta do Mississippi

3.2 - Costa com planície aluvial... NW da Índia

3.3 - Costa com planície de lavagem... SE da Islândia

3.4 - Costa com vulcões... Ilhas do Havaí

3.5 - Costa com recifes... Grandes Recifes de Barreiras (NE da Austrália)

3.6 - Costa falhada... Nova Zelândia (Wellington)

4. COSTAS COMPOSTAS: qualquer combinação das três anteriores. 
islands) são típicas de costas de submersão (Russell, 1958; Hoyt, 1967). Como exemplo de costa de submersão tem-se o litoral oriental dos Estados Unidos e de deltas abandonados tem-se a foz do Rio Amazonas no Brasil.

Uma classificação bastante diferente da proposta por Johnson (1919) foi apresentada por Valentin (1952), embora também faça uso de termos como costas de submersão e de emersão (Tab. II).

As tendências dos movimentos verticais, na classificação acima, foram obtidas de dados maregráficos, mas em muitas regiões do mundo, não existem séries temporais muito longas dessas informações que, em geral, raramente ultrapassam algumas dezenas de anos. Desta maneira, a costa de avanço ou de regressão marinha resulta da descensão de nível do mar, soerguimento do continente adjacente ou da combinação de ambos e a costa de recuo ou de transgressão marinha deve-se à ascensão de nível do mar, subsidência do continente adjacente ou da combinação de ambos (Fig. 1) que, segundo Bloom (1965), requer a adição de uma escala temporal específica. Shepard (1967) apresentou uma revisão da sua proposta anterior de 1937, admitindo a subdivisão maior das costas em costas primárias e costas secundárias, conforme Fig. 2.

Segundo King (1972), o fato de terem sido propostas diversas classificações indica que, qualquer trecho de região litorânea, pode ser definido segundo vários critérios, que desempenharam os seus papéis atribuindo-lhe características peculiares. Esta autora acrescentou ao quadro com dezoito critérios de classificação, elaborado por Tanner (1960), outros dois pesquisadores, totalizando treze auto-

Tabela II. Classificação de costas segundo H. Valentin (1952).

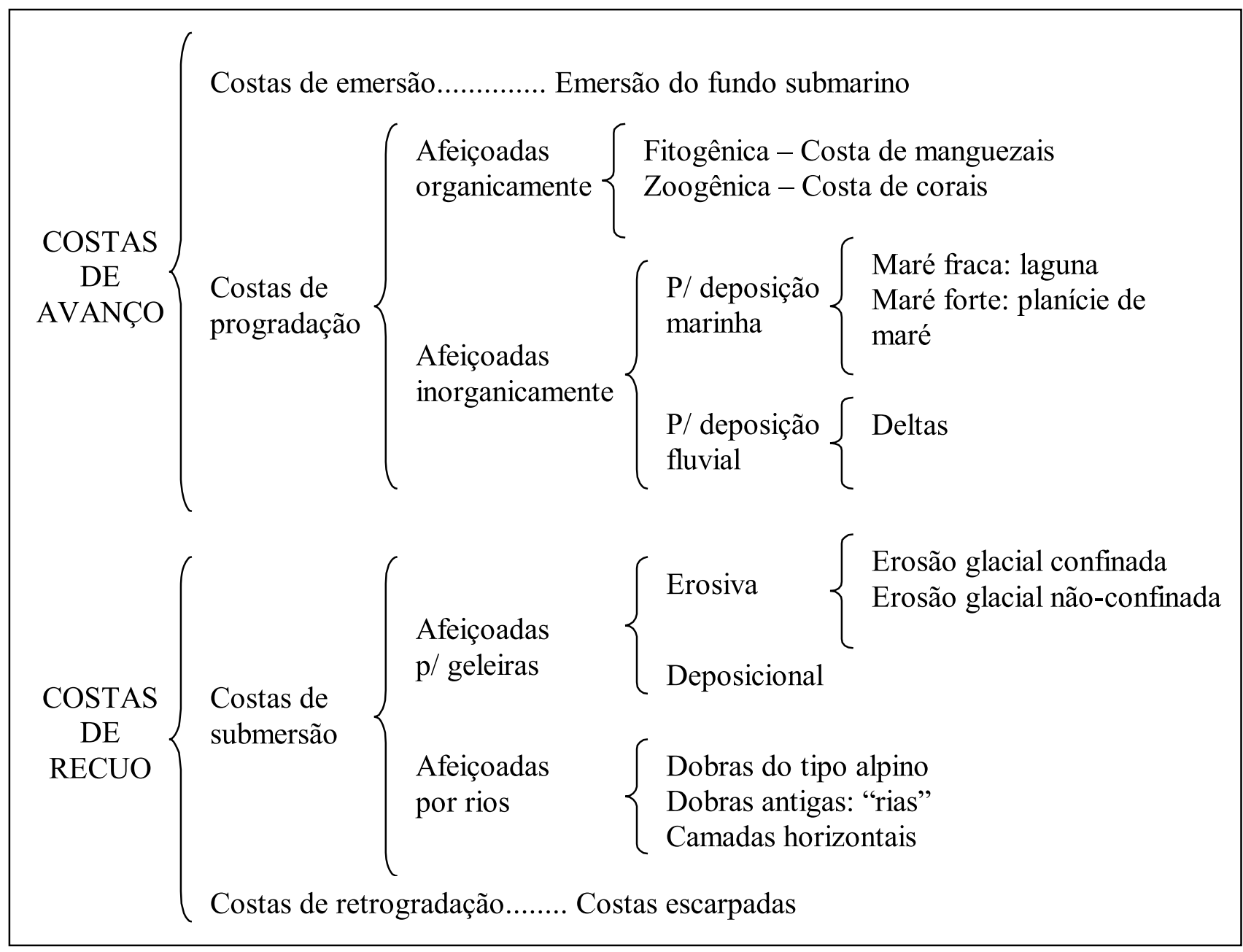




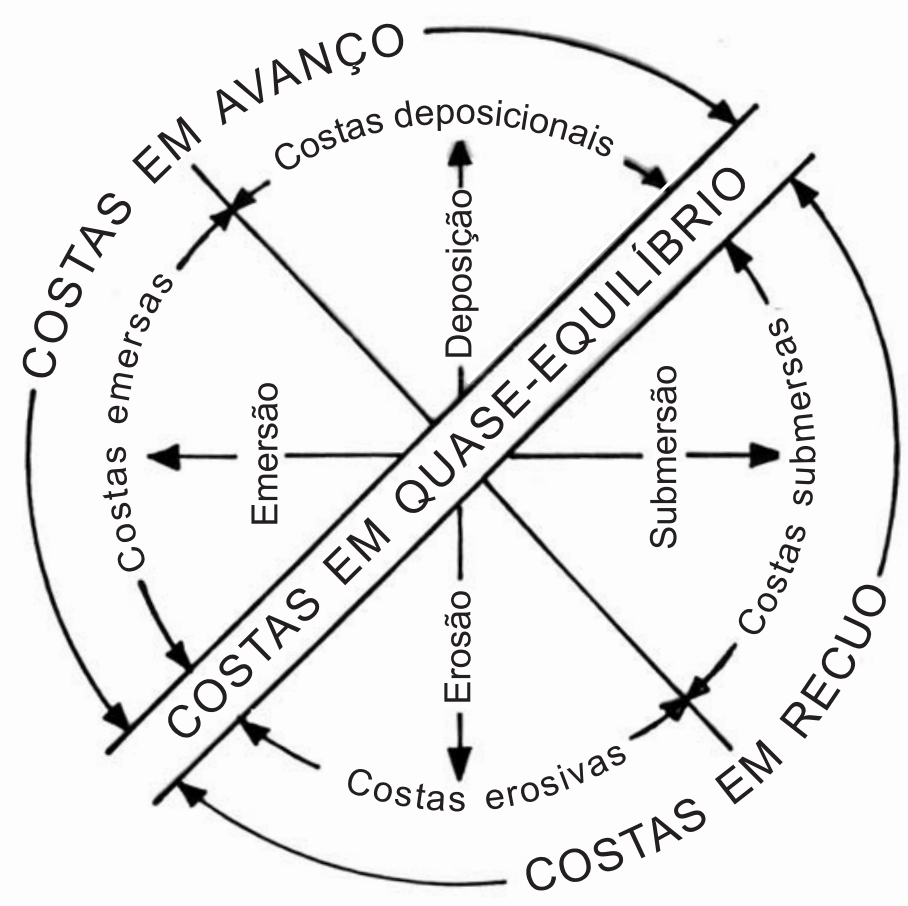

Figura 1. Diagrama representando costas em avanço (por emersão ou por deposição) e costas em recuo (por submersão ou por erosão) segundo Valentin (1952).

res (Tab. III). Por essa tabela pode-se constatar que alguns dos critérios foram usados por vários pesquisadores, enquanto outros foram considerados por poucos autores. Provavelmente os critérios usados por maior número de pesquisadores seriam mais significativos.

Apesar da existência de tantas classificações, pode-se dizer que nenhuma é plenamente satisfatória. Algumas são puramente descritivas, enquanto outras são essencialmente genéticas. De qualquer modo, três parecem ser as variáveis que devem ser levadas em consideração em qualquer definição: configurações das zonas de contato continente-oceano, os movimentos relativos do nível do mar e os efeitos dos processos marinhos.

Russell (1967) considerava que qualquer tentativa de classificação era prematura, pois ele defendia que a taxonomia deveria seguir e não preceder a fase de obtenção de informações mais precisas sobre os diferentes tipos de zonas litorâneas. De fato, até hoje existem relativamente poucas informações sobre as regiões litorâneas, apesar de inúmeras pesquisas executadas em diversas partes do mundo por diferentes autores. Desta maneira verificou-se, por exemplo, a impossibilidade de obtenção de uma curva-padrão mundial para as variações dos níveis relativos do mar pós-glaciais, pois este parâmetro depende de causas mundiais, regionais e locais, que atuam em escalas temporais e espaciais diversas. Este fato foi confirmado somente na década de 70, contrariamente às idéias anteriores de Fairbridge (1961). Por outro lado, o estudo dos deltas quaternários brasileiros (Martin et al., 1993) veio demonstrar que a história evolutiva do delta do Rio Mississippi (Estados Unidos), talvez o mais estudado no mundo, não serve de paradigma para o entendimento da sedimentação deltaica em geral. Entretanto, ao invés da posição sectária assumida por Russell (op. cit.), é possível que uma atitude mais comedida e proveitosa seja a de se estabelecer uma classificação em qualquer estágio de conhecimento, que necessariamente deverá sofrer revisão periódica em função de novos conhecimentos. 


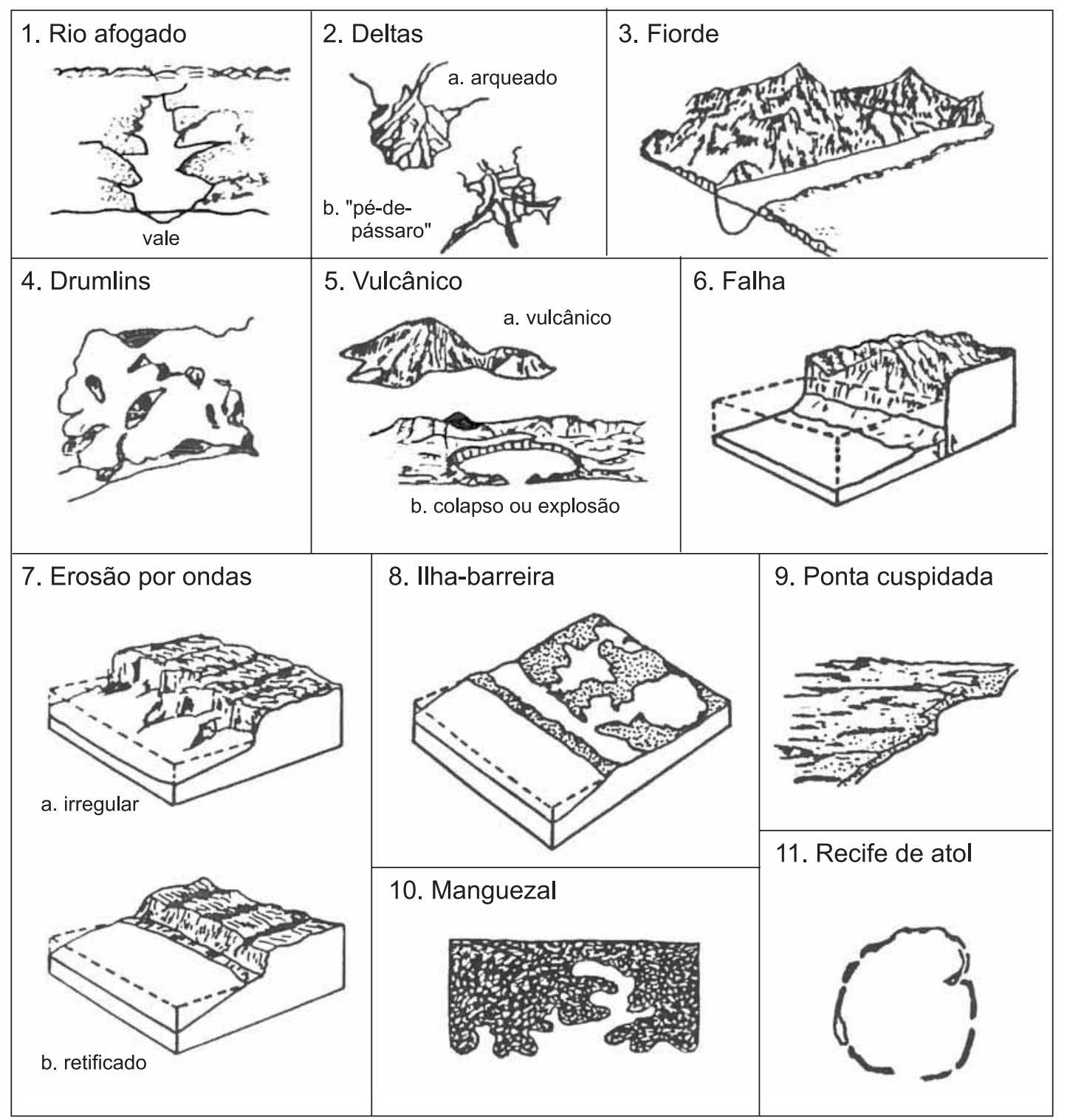

Figura 2. Tipos de costas segundo a classificação de Shepard (1967).

\section{I.3. Classificação da região litorânea do Brasil}

Raja Gabaglia (1916) foi talvez o primeiro autor, que distinguiu no litoral brasileiro, os seguintes trechos:

a) Costa de mangues - do Cabo Orange ao Cabo Norte;

b) Costa de estuário - região do Baixo Amazonas; c) Costa mista - da Ponta da Tijoca à foz do Rio Parnaíba;

d) Costa dunosa - da foz do Rio Parnaíba ao Cabo de Santo Antônio;

e) Costa concordante - do Cabo de Sto Antônio à foz do Rio Araranguá;

f) Costa arenosa - da foz do Rio Araranguá à desembocadura do Arroio Chuí. 
Tabela III. Critérios geocientíficos de classificação de regiões litorâneas (King, 1972).

\begin{tabular}{|c|c|c|c|c|c|c|c|c|c|c|c|c|c|}
\hline Parâmetros & 1 & 2 & 3 & 4 & 5 & 6 & 7 & 8 & 9 & 10 & 11 & 12 & 13 \\
\hline a. Tipo de estrutura & $x$ & & & & $x$ & & $\mathrm{x}$ & & & & $x$ & & $X$ \\
\hline b. Estabilidade da estrutura & & & & & & $\mathrm{X}$ & & & $x$ & & & & \\
\hline c. Movimentos horizontais & & & & & & & & $X$ & & & & & $X$ \\
\hline d. Movimentos verticais & & $x$ & $\mathrm{x}$ & $\mathrm{X}$ & & $\mathrm{X}$ & $\mathrm{x}$ & $\mathrm{X}$ & & & & & $x$ \\
\hline e. Agentes atuais & & & & & $X$ & & $X$ & $\mathrm{X}$ & $X$ & & & & \\
\hline f. Agentes pretéritos & & $x$ & & $x$ & $\mathrm{X}$ & & & & & & & & $x$ \\
\hline g. Materiais do substrato & & & & & & & & & $x$ & $x$ & & & \\
\hline h. Materiais em trânsito & & & & & & & & & $x$ & $x$ & & & \\
\hline i. Tipo de energia & & & & & & & & & $x$ & $x$ & & $x$ & \\
\hline j. Nível de energia & & & & & & & & & $x$ & $x$ & & $\mathrm{X}$ & \\
\hline k. Padrão geométrico & $x$ & $x$ & $x$ & $x$ & & & & & $x$ & $x$ & $x$ & & \\
\hline I. Equilíbrio costeiro & & $x$ & & & & & & & & $x$ & & & \\
\hline m. Perfil transversal & & $x$ & $x$ & $x$ & & & & & $x$ & & & $x$ & \\
\hline n. Razão erosão/ deposição & & & & & $\mathrm{x}$ & & $\mathrm{x}$ & & & & & $x$ & $x$ \\
\hline o. Estádio ou idade & & $x$ & & $x$ & & & & & & & & & \\
\hline p. Clima & & & & & & & & $x$ & $\mathrm{x}$ & & & $x$ & \\
\hline \multicolumn{14}{|l|}{ q. Ecologia } \\
\hline r. Tempo & & & & & & & & $X$ & & & & & $x$ \\
\hline
\end{tabular}

1. E. Suess; 2. W. M. Davis; 3. F. P. Gulliver; 4. D. W. Johnson; 5. F. P. Shepard; 6. C. A. Cotton; 7. R. H. Fleming \& F. E. Elliott; 8. H. Valentin; 9. W. A. Price; 10. W. F. Tanner; 11. A. Guilcher; 12. J. A. Davies; 13. A. L. Bloom. 
Segundo Silveira (1964), pouco mais tarde o autor supracitado passou a distinguir duas porções que designou de Litoral do Nordeste (do Cabo Orange à Ponta do Calcanhar) e Litoral de Sudoeste (da Ponta do Calcanhar ao Arroio Chuí). Verifica-se que na classificação da tabela III foi adotada uma miscelânea de critérios, pois os diferentes trechos são designados pelo tipo de vegetação (costa de mangues), origem do sedimento (costa dunosa), composição do sedimento (costa arenosa) etc. Por outro lado, essas características não podem ser exclusivas dos trechos especificados.

Delgado de Carvalho (1927) reviu a classificação de Raja Gabaglia (op. cit.) e enfatizou outros aspectos, como as idades (terciária ou quaternária) e as origens, reconhecendo quatro trechos diferenciados no litoral brasileiro:

a) Costa quaternária do norte - do Amapá ao Maranhão;

b) Costa terciária - do Piauí ao Cabo Frio;

c) Costa eruptiva - do Cabo Frio à Laguna;

d) Costa quaternária do sul - de Laguna ao Chuí.

Finalmente, Silveira (1964) considerou elementos oceanográficos, climáticos e continentais, que caracterizam os diversos trechos do litoral brasileiro, propondo cinco trechos (Fig. 3):

a) Litoral amazônico ou equatorial - da Foz do Rio Oiapoque ao Maranhão Oriental;

b) Litoral nordestino ou das Barreiras Maranhão Oriental ao Recôncavo Baiano;

c) Litoral oriental - do Recôncavo Baiano ao norte do Espírito Santo;

d) Litoral sudeste ou das escarpas cristalinas - do sul do Espírito Santo à região de Laguna;

e) Litoral meridional ou subtropical - da região de Laguna à foz do Arroio Chuí.

\section{I.3.1. O litoral amazônico ou equatorial}

Compreende um trecho de mais de $1.500 \mathrm{~km}$ de extensão e largura que, em alguns setores, passa de $100 \mathrm{~km}$. Em geral, é formado por terras baixas periodicamente inundáveis, de idade quaternária que, no interior passa para sedimentos terciários da Formação Barreiras. Localmente estes depósitos mais antigos atingem a zona litorânea e formam falésias, algumas ativas e outras inativas. Muitas dessas falésias mortas podem representar antigas linhas de costa. Em função do sedimento lamoso do Rio Amazonas, que é depositado quase somente a NW da sua foz, no litoral amazônico podem ser distinguidas a costa

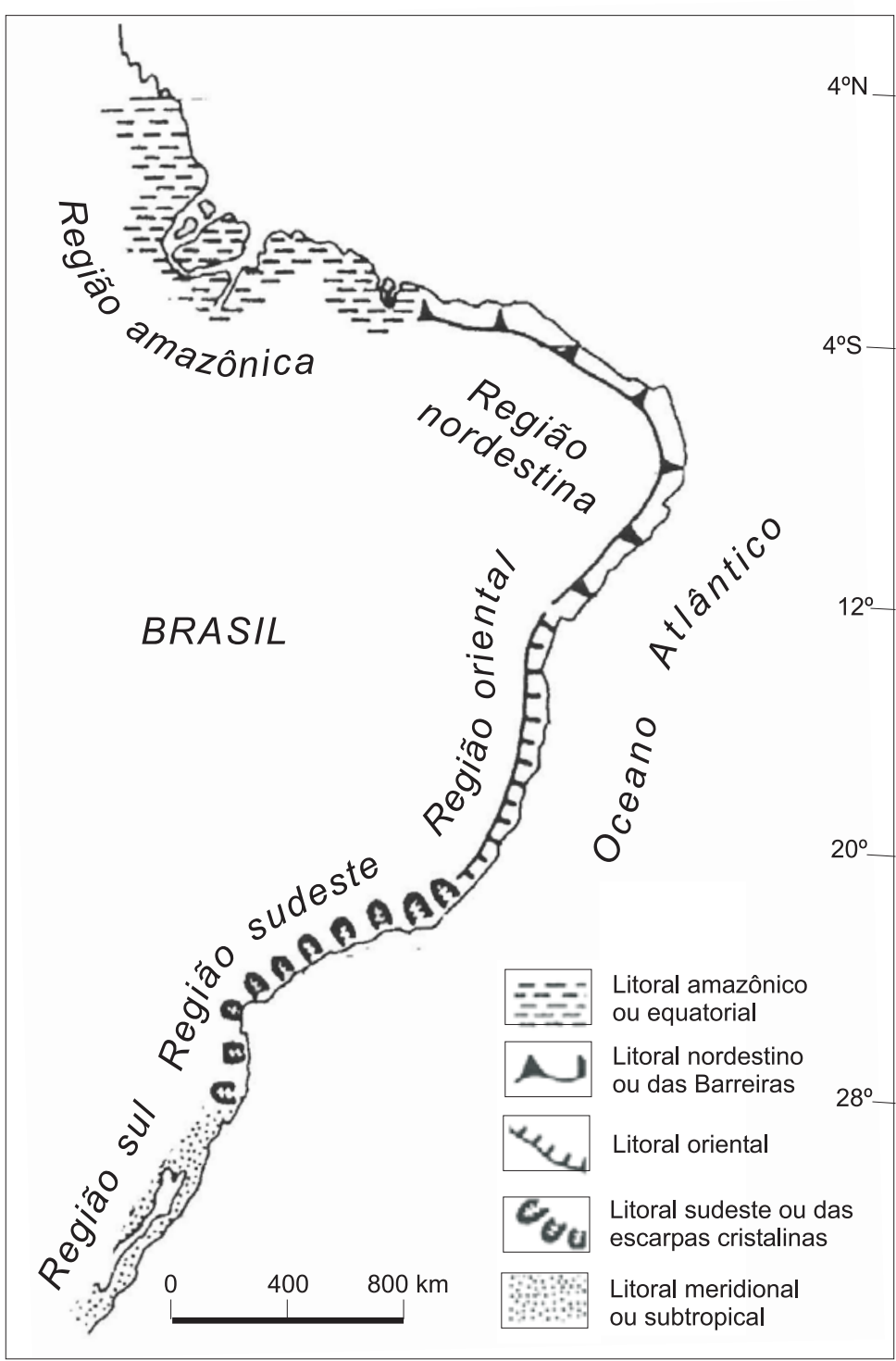

Figura 3. Subdivisão do litoral brasileiro, baseada em critérios oceanográficos, climáticos e continentais segundo Silveira (1964). 
do Amapá (Litoral güianense) da costa do leste do Pará e do Maranhão. Deste modo, segundo Silveira (op. cit.), no litoral amazônico distinguem-se três setores principais: Litoral güianense, Golfão amazônico e Litoral amazônico oriental.

Por outro lado, o substrato lamoso com águas rasas, do litoral amazônico, favoreceu o estabelecimento dos manguezais mais exuberantes do litoral brasileiro (Schaeffer-Novelli et al., 1990).

\section{I.3.2. O litoral nordestino}

Estende-se da foz do Rio Parnaíba ao Recôncavo Baiano, tendo como características comuns a presença de sedimentos terciários da Formação Barreiras, os recifes de rochas praiais (beach rocks) e de corais.

A Formação Barreiras, que ocorre desde o litoral amazônico, acompanha o litoral à retaguarda da planície quaternária e acha-se delimitada ao interior por um relevo bem mais acidentado de rochas cristalinas pré-cambrianas. Esta unidade geológica forma um relevo popularmente conhecido como "tabuleiro", que se caracteriza por um topo plano e suavemente inclinado para o Oceano Atlântico e mais ou menos dissecado por vales fluviais de vertentes relativamente íngremes. Onde a sedimentação litorânea se torna escassa ou é inexistente, a linha de costa é definida por escarpas ou falésias marinhas da Formação Barreiras, exibindo uma paisagem bastante comum não somente no litoral nordestino, mas até nos litorais oriental e sudeste (Martin et al., 1999).

A palavra "recife" é de origem náutica, referindo-se a quaisquer obstáculos situados em águas rasas que atrapalham a navegação. Neste contexto, o litoral nordestino apresenta recifes de ferricretes (duricrostas), isto é, crostas ferruginosas ligadas à Formação Barreiras, às rochas praiais (arenitos e conglomerados) e aos corais hermatípicos (construtores de recifes). As rochas praiais são compostas de grãos de areia ou cascalho cimentados naturalmente por $\mathrm{CaCO}_{3}$ (carbonato de cálcio) fornecido pelas águas do mar, formando rochas muito duras (litificadas) descritas em certo detalhe por Branner em 1904, cuja idade é praticamente restrita à época holocênica (em geral inferior a 5.000 anos), segundo datações executadas por Flexor \& Martin (1979). Os corais são estruturas biogenéticas, construídas por animais invertebrados tipicamente marinhos e coloniais denominados celenterados, que vivem em simbiose com certos tipos de algas. Juntamente com os corais desenvolvem-se também algas secretoras de $\mathrm{CaCO}_{3}$ como Lithothamnium e Halimeda. Esta associação forma os chamados recifes de corais, de composição essencialmente carbonática, incrustados sobre a superfície dura de recifes ferruginosos e/ou de rochas praiais.

Por outro lado, no litoral nordestino podem ser reconhecidos dois setores: o primeiro abrange os litorais dos estados do Piauí, Ceará e metade noroeste do Rio Grande do Norte constituindo a costa semi-árida e a metade sul do Rio Grande do Norte até o Recôncavo Baiano caracterizada por clima úmido, que forma a costa nordeste oriental ou das Barreiras. A costa semi-árida apresenta freqüentemente pluviosidade inferior a $500 \mathrm{~mm} /$ ano e, deste modo, as areias abundantes de granulação fina provenientes da plataforma rasa adjacente secam-se rapidamente e os incessantes ventos alísios atuam no transporte eólico desses sedimentos, que originam os campos de dunas, muito abundantes no Ceará e Rio Grande do Norte. O substrato arenoso e eólico extremamente móvel e o litoral pouco recortado explicariam, em parte, a escassez de manguezais neste trecho, apesar de clima bastante favorável. Na costa nordeste oriental ou das Barreiras, além das peculiaridades que tipificam todo o litoral nordestino (ocorrências dos tabuleiros da Formação Barreiras, rochas praiais e corais hermatípicos), o clima mais úmido permite uma melhor fixação das areias e a sua natureza mais recortada enseja a formação de estuários, onde se desenvolvem mais manguezais que no trecho anterior. Além disso, neste trecho do litoral nordestino, os cursos fluviais que são bastante escassos na costa semi-árida, ganham maior projeção através do Rio São Francisco, que constitui o mais extenso rio essencialmente brasileiro que, na sua desembocadura, no Oceano Atlântico, forma o complexo deltaico homônimo (Martin et al., 1993).

\subsubsection{O litoral oriental}

Situa-se entre o Recôncavo Baiano e o norte do Estado do Espírito Santo. Embora neste trecho ainda persistam as características principais do litoral nordestino, acima enumeradas, já aparecem vários traços próprios. $\mathrm{O}$ primeiro deles é a existência de uma plataforma submarina rasa como o Arquipélago de Abrolhos, onde se situam as ocorrências mais meridionais de recifes de corais do litoral brasileiro (Leão \& Kikuchi, 1999). Neste trecho a largura da plataforma continental que, em geral não ultrapassa os $30 \mathrm{~km}$ no litoral nordestino, alarga-se para mais de $70 \mathrm{~km}$ ao longo de cerca de $150 \mathrm{~km}$ da costa, entre o sul da Bahia 
e o norte do Espírito Santo. A segunda característica é que, neste litoral, desembocam vários cursos fluviais importantes (Pardo, Contas, Jequitinhonha, Doce etc). A existência desses cursos fluviais e as flutuações do nível do mar no Período Quaternário explicam a terceira peculiaridade do litoral oriental, que é a existência de extensas planícies de cordões litorâneos arenosos. Como alguns exemplos dessas planícies tem-se os complexos deltaicos associados à desembocadura dos rios Jequitinhonha (BA), conforme estudos de Martin et al. (1993, 1997).

De modo semelhante ao litoral nordestino, o litoral oriental também exibe três unidades geomorfológicas distintas que, da costa para o interior, compreendem as seguintes unidades: a planície litorânea de idade quaternária, os "tabuleiros" da Formação Barreiras de idade terciária e a região montanhosa constituída por rochas cristalinas pré-cambrianas. As escarpas do Planalto Atlântico ainda se acham bastante afastadas do litoral e só muito excepcionalmente afetam as formas litorâneas.

Uma das feições mais espetaculares do litoral oriental é o Recôncavo Baiano, onde se inicia este trecho da costa. Corresponde a um golfo que penetra cerca de $80 \mathrm{~km}$ para o interior do continente e o seu perímetro atinge quase $300 \mathrm{~km}$, ocupando uma área total superior a $1.000 \mathrm{~km}^{2}$.

\subsubsection{O litoral sudeste ou das escarpas cristalinas}

Compreende o setor situado entre o sul do Espírito Santo e o Cabo de Santa Marta Grande (SC). Entre algumas das particularidades deste trecho, que se inicia nas cercanias de Vitória (ES), tem-se o Planalto Atlântico cujas rochas cristalinas pré-cambrianas alcançam a orla litorânea com grande freqüência e as lagunas costeiras.

Embora neste trecho do litoral brasileiro ocorram sedimentos terciários (formações Barreiras, Pariqüera-Açu e Alexandra), as feições gerais são definidas pelo Planalto Atlântico e pelas planícies litorâneas freqüentemente interrompidas por promotórios, que delimitam trechos restritos de planícies com "praias-de-bolso".

Duas feições geomorfológicas, que se destacam neste litoral, são as baías de Guanabara (RJ) e Paranaguá (PR), além do complexo deltaico do Rio Paraíba do Sul, RJ (Martin et al., 1988a 1993, 1997).

Outro fato interessante deste trecho do litoral brasileiro é que, excetuando-se os rios Paraíba do Sul (RJ) e Ribeira de Iguape (SP), outros cursos fluviais dirigem-se para o interior do continente e não para o oceano, exemplificados pelos rios Tietê (SP) e Iguaçu (PR), que depois de percorrer várias centenas de quilômetros deságuam no Rio Paraná.

Nos litorais fluminenses, parte norte paulista e no paranaense, o Planalto Atlântico chega a ultrapassar $800 \mathrm{~m}$ de altitude representando, na maioria das vezes, escarpas de falha recuadas por erosão. A maioria dessas falhas originou-se no Pré-cambriano, porém foram reativadas em várias ocasiões, cujas atividades mais intensas ocorreram durante a abertura do Oceano Atlântico e concomitante formação e preenchimento das bacias costeiras ou marginais (Campos, Santos etc), desde cerca de 150 até 50 milhões de anos passados. Até hoje muitas dessas falhas exibem alguma atividade tectônica.

Finalmente ao sul do Estado de Santa Catarina, na região de Laguna, são encontrados os últimos manguezais atuais da costa brasileira.

\section{I.3.5. O litoral meridional ou subtropical}

Começando em Laguna (SC), rumo ao sul, o litoral brasileiro é quase que inteiramente baixo e arenoso, com maior desenvolvimento da planície litorânea. Entretanto, mesmo neste trecho, entre a planície quaternária e as rochas cristalinas pré-cambrianas ocorrem sedimentos terciários denominados de Formação Graxaim.

Em geral, tanto ao sul de Santa Catarina como no Rio Grande do Sul a paisagem é bastante monótona, mas uma das feições bastante típica deste setor são as lagunas costeiras, entre as quais sobressai a Laguna dos Patos, que ocupa uma área de cerca de $10.000 \mathrm{~km}^{2}$. Outro aspecto característico deste litoral são as dunas eólicas, que são muito freqüentes.

\section{AS PLANíCIES COSTEIRAS OU BAIXADAS LITORÂNEAS}

\section{II.1. O que são planícies costeiras?}

As planícies costeiras são superfícies geomorfológicas deposicionais de baixo gradiente, formadas por sedimentação predominantemente subaquosa, que margeiam corpos de água de grandes dimensões, como o mar ou oceano, representadas comumente por faixas de 
terrenos recentemente (em termos geológicos) emersos e compostos por sedimentos marinhos, continentais, fluviomarinhos, lagunares, paludiais etc, em geral de idade quaternária.

As planícies costeiras compostas por séries de cristas praiais (cordões litorâneos ou cordões arenosos), mais ou menos paralelas entre si e formadas predominantemente por areias (Fig. 4), representam uma costa de progradação ou costa de avanço por sedimentação (Valentin, 1952). As séries paralelas de cristas praiais são, em geral, separadas entre si por superfícies de truncamento possivelmente correspondentes a fases de mudanças nos sentidos de incidência dos "trens de ondas", pois essas feições são essencialmente ligadas às ondas marinhas. Este tipo de planície costeira, onde se verifica predominância de cristas praiais são relativamente comuns no litoral brasileiro, onde são muitas vezes conhecidas pela designação imprecisa de "planícies de restinga". Como exemplos tem-se as desembocaduras dos rios Doce (ES) e Paraíba do Sul (RJ), estudadas respectivamente por Suguio et al. (1982) e Martin et al. (1984a), que constituem casos particulares de planícies costeiras situadas nas desembocaduras de importantes cursos fluviais. A cidade de Santos (SP), que não se encontra nesta situação, foi quase inteira-

\section{a) Bloco-diagrama}

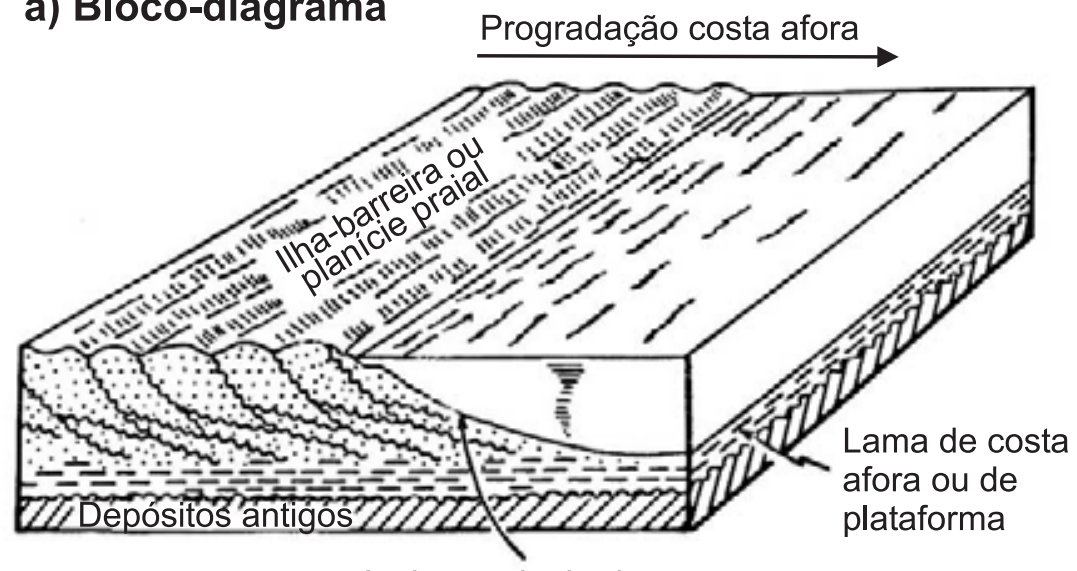

Areia retrabalhada por erosão de face de praia

\section{b) Seção}

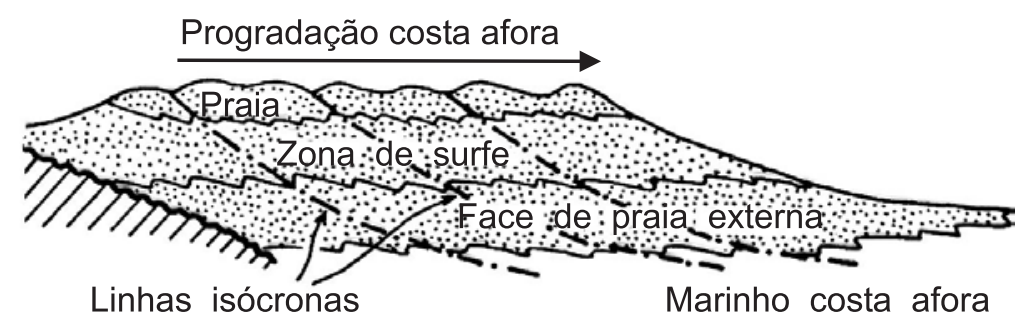

Figura 4. Vistas tridimensional (a) e em perfil (b) de uma costa de progradação, através de sucessivos alinhamentos de cristas praiais (cordões litorâneos ou cordões arenosos), em linha costeira regressiva. 
mente construída sobre planícies costeiras holocênicas (últimos 10.000 anos), comumente sotopostas por depósitos pleistocênicos.

Um outro tipo de planície costeira desenvolve-se, por exemplo, a sudoeste de Louisiana (Estado Unidos), que é constituído por uma sucessão de cristas praiais arenosas de 50 a $500 \mathrm{~m}$ de largura, algumas dezenas de quilômetros de comprimento e 5 a $10 \mathrm{~m}$ de espessura, separadas entre si por sedimentos argilosos e/ou orgânicos (Hoyt, 1969). A designação planície de chênier para este tipo de planície costeira deve-se a Price (1955) na Lousiana, onde a sua largura total chega a $35 \mathrm{~km}$ e estende-se por $180 \mathrm{~km}$ ao longo do litoral. Porém, as planícies deste tipo mais extensas do mundo com $1.600 \mathrm{~km}$, ocorrem nas Güianas, que recebem volumes fantásticos de carga sólida lamosa do Rio Amazonas (Gibbs, 1976). No Brasil, planície de chênier de dimensões bem mais modestas é encontrada no litoral do Pará (Franzinelli, 1982). O desenvolvimento deste tipo de planície é característico de litoral que recebe grande suprimento de lama e pouca areia sendo submetido, além disso, a fases erosivas períodicas.

Além das planícies costeiras de cristas praiais e de chênier, principalmente onde os níveis do mar apresentaram tendência à descensão durante, no mínimo mais de 1.500 anos, podem ocorrer depósitos lagunares, lacustres e paludiais. Por outro lado, trechos de costa com abundante suprimento de areias finas, submetidos a constante retrabalhamento eólico sob condições semi-áridas, podem exibir excepcional desenvolvimento de campos de dunas eólicas costeiras, como acontece nos "lençóis maranhenses". As baixadas costeiras extensas com climas quentes e secos podem favorecer o surgimento de planicies salinas ou sebkhas costeiras, exibindo crostas evaporíticas e faixas de tapetes algálicos.

\section{II.2. Como e quando se formaram as planícies costeiras?}

\section{II.2. 1. Causas paleoclimáticas}

Os materiais que constituem as planícies costeiras, principalmente na maior parte do litoral brasileiro, onde prevalecem condições de quiescência tectônica, a principal causa de formação das planícies costeiras ou baixadas litorâneas é a glacioeustasia (Fig. 5).

A glacioeustasia refere-se às variações do nível relati- vo do mar devido aos fenômenos glaciais, isto é, de natureza climática. Nos estádios glaciais (fases de expansão das geleiras), ocorrendo à retenção de grandes volumes de água sobre os continentes, verifica-se a descensão do nivel relativo do mar. Contrariamente, nos estádios interglaciais (fase de retração das geleiras), com diminuição dos volumes de água retidos sobre os continentes, constata-se ascensão do nível relativo do mar (Fig. 6). Embora a atuação deste fenômeno não ocorra simultaneamente no mundo inteiro, havendo interligação entre os vários oceanos, mais cedo ou mais tarde acaba estendendo-se globalmente.

Embora alguns fenômenos ligados à tectonoeustasia, isto é, variações dos níveis do mar por movimentos crustais, como a tectônica de placas apresente também um caráter global, são bastante comuns os fenômenos tectonoeustáticos de alcances regional ou mesmo local que, na verdade, podem ser mais evidentes que os efeitos globais.

Como se vê na Fig. 5, entre outros fatores causadores das variações do nível relativo do mar têm-se os fenômenos geoidais (geoidoeustasia) ou, ainda, de naturezas muito limitadas em termos de escalas temporal e/ou espacial, como os fenômenos meteorológicos e os efeitos de compactação diferencial ou de assoreamento por sedimentos (sedimentoeustasia).

\section{II.2.2. Reconstrução dos níveis do mar pretéritos}

A reconstrução de antigas posições ocupadas pelos níveis relativos do mar só se torna possível com a definição de um indicador (evidência ou testemunho) deste fato, no espaço e no tempo. Para a definição de um indicador no espaço é necessário conhecer a altitude da formação ou de deposição em relação ao nível do mar da época. Por outro lado, para se situar um indicador no tempo é preciso determinar a idade de sua formação ou deposição, de preferência através de métodos geocronológicos, usando-se algum radioisótopo. $\mathrm{O}$ indicador, assim definido, fornece a posição relativa do nível do oceano em um determinado local naquele instante.

Se for possível obter um número, suficientemente grande (algumas dezenas) de antigas posições ocupadas pelos níveis relativos do mar, cobrindo, um setor de costa durante um intervalo de tempo, pode-se tentar delinear uma curva de variações para aquele trecho de costa no intervalo de tempo considerado. É óbvio que o setor de 


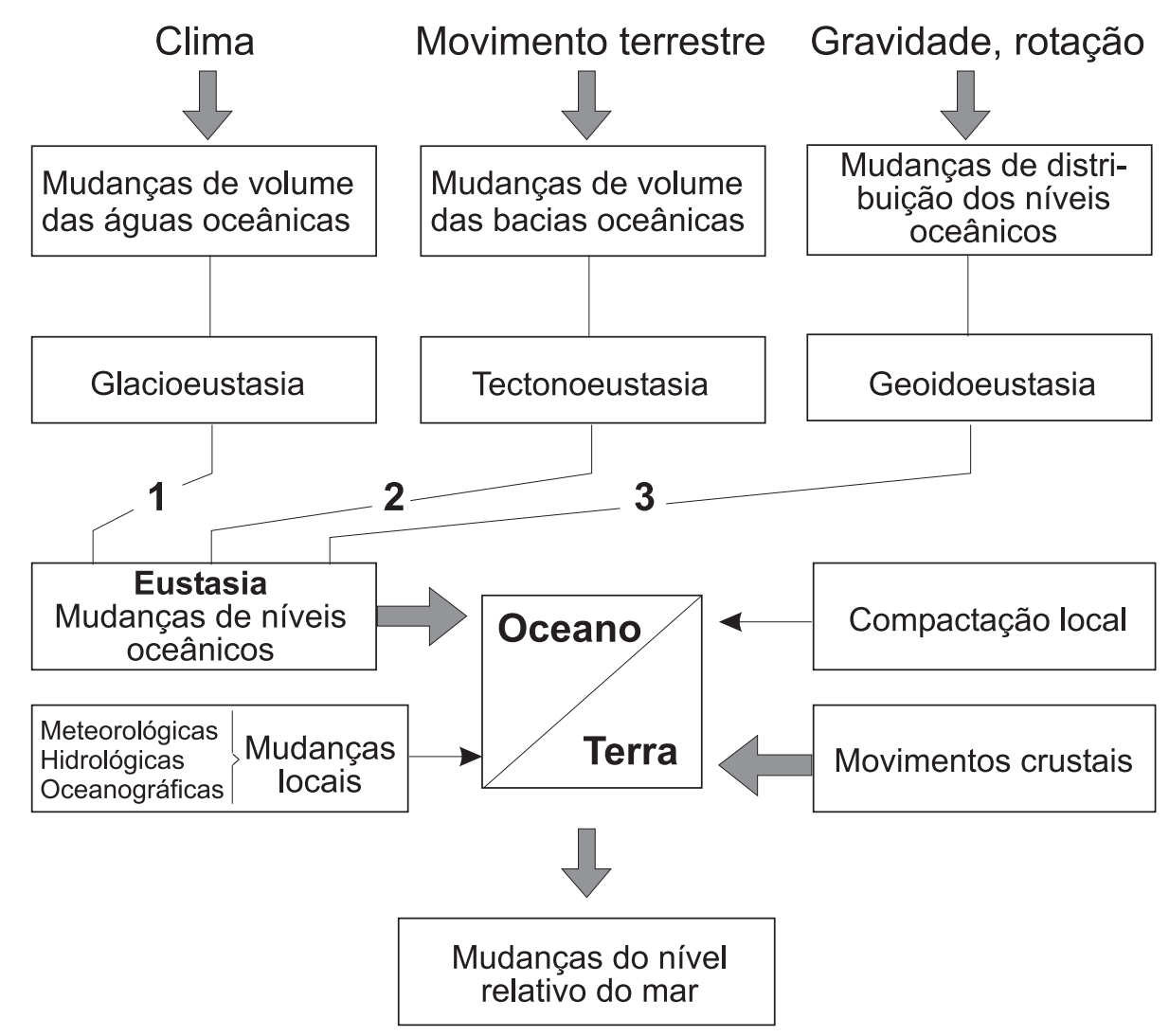

Figura 5. Os principais fatores que influem na variação do nível do mar no Quaternário, incluindo os fatores mundiais, regionais e locais (Martin et al. 1986a).

costa considerado deve ser homogêneo em termos geológicos exibindo, por exemplo, comportamento tectônico semelhante. Deste modo, com alguma freqüência, tem-se que optar entre:

a) construir uma curva baseada em grande número de informações, mas envolvendo longo trecho de costa (algumas centenas de quilômetros de extensão), eventualmente com comportamentos tectônicos distintos, ou

b) considerar um trecho mais limitado da costa (algumas dezenas de quilômetros de extensão), o que poderá implicar em menor número de reconstruções e, portanto, em curvas menos precisas e talvez, até mesmo, insuficientes para delinear uma curva completa.

\section{II.2.2.1. Evidências de níveis relativos do mar abaixo do atual}

A margem continental brasileira entre Torres e Chuí, no Rio Grande do Sul, é do tipo tectonicamente estável no Período Quaternário, estando submetida em épocas mais recentes somente a movimentos epirogênicos (movimentos ascensionais verticais) bastante suaves. Desta maneira, as peculiaridades fisiográficas são unicamente atribuíveis aos fenômenos deposicionais e erosivos (Fig. 7), que resultaram dos últimos eventos transgressivos (avanço do mar continente adentro) e regressivos (recuo do mar costa afora) posteriormente ao UMG (Último Máximo Glacial), que atuou predominantemente no hemisfério norte. Entre 

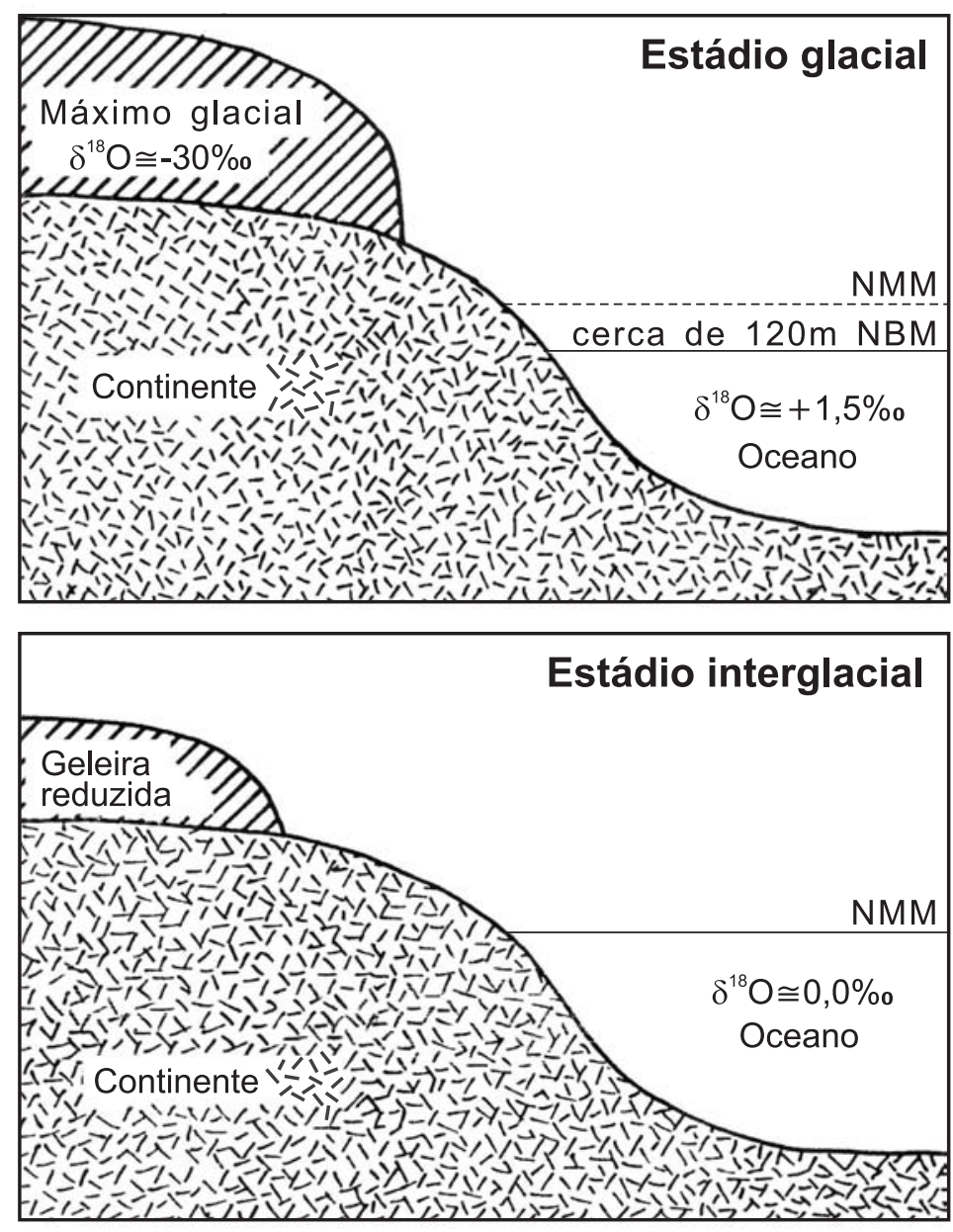

Figura 6. Variações nos tamanhos (áreas e espessuras) das geleiras e das razões isotópicas $\left(\delta^{18} \mathrm{O}\right)$ das águas superficiais durante os estádios glaciais e interglaciais (Lowe \& Walker, 1997).

Torres e Mostardas, a plataforma continental é estreita e as curvas batimétricas são mais homogêneas. De Mostardas ao Chuí, a plataforma torna-se mais larga e apresentase dissecada por muitos paleovales escavados por antigos canais fluviais e, além disso, exibe inúmeros bancos arenosos.

Os estudos desta plataforma continental levaram ao reconhecimento de muitas escarpas submersas, com vertentes mais acentuadas, representando posições de estabilização de antigos níveis do mar. Elas foram seguidas continuamente de Torres a Chuí e acham-se situadas nas profundidades entre $20-26 \mathrm{~m}, 32-45 \mathrm{~m}$, 60 - 70 m, 100 - 110 m, 120 - 130 m (Corrêa, 1979). Kowsmann et al. (1977) e Corrêa (1996) propuseram que o nível de 120 - 130 m seja o limite de regressão (recuo do mar costa afora) máxima, de idade pleistocênica tardia correspondente ao UMG, há aproximadamente 17.500 anos AP (Antes do Presente). Com base na curva eustática apresentada por Corrêa (1990), três fases mais importantes de evolução paleogeográfica podem ser reconhecidas na plataforma continental entre Torres e Chuí(Fig. 8):

a) Primeira fase (de 17.500 a 16.000 anos $A P$ ) - há cerca de 17.500 anos AP, quando o nível relativo do mar achava-se 120 a $130 \mathrm{~m}$ abaixo do atual, praticamente toda a plataforma continental estava emersa e submetida à intensa erosão subaérea. Esta superfície originalmente plana foi dissecada por vales fluviais, que hoje são reconhecidos sobre mapas batimétricos.

Os sedimentos depositados ao longo desta costa eram constituídos de areia fina na plataforma interna e de areias lamosas a lamas na plataforma externa e talude continentais. As areias grossas, representativas de paleolinhas de praia, foram supridas parcialmente pelos cursos fluviais e também pelo retrabalhamento dos sedimentos sotopostos (situados abaixo).

Neste intervalo de tempo a elevação do nível do mar foi rápida ( $2 \mathrm{~cm} / \mathrm{ano})$, sendo estabilizada há cerca de 16.000 anos AP. A paleolinha de praia correspondente a esta fase é representada por areias médias, provavelmente estuarinas ou deltaicas, provenientes das paleodrenagens costeiras.

b) Segunda fase (de 16.000 a 11.000 anos $A P)$ - a velocidade de ascensão do nível relativo do mar diminuiu de cerca de $2 \mathrm{~cm} /$ ano para $0,6 \mathrm{~cm} /$ ano.

Esta fase é representada na sucessão litológica por areias lamosas de ambiente pré-litorâneo, comumente situadas na base da seqüencia transgressiva. Esta seqüência transgressiva está situada entre as plataformas continen- 


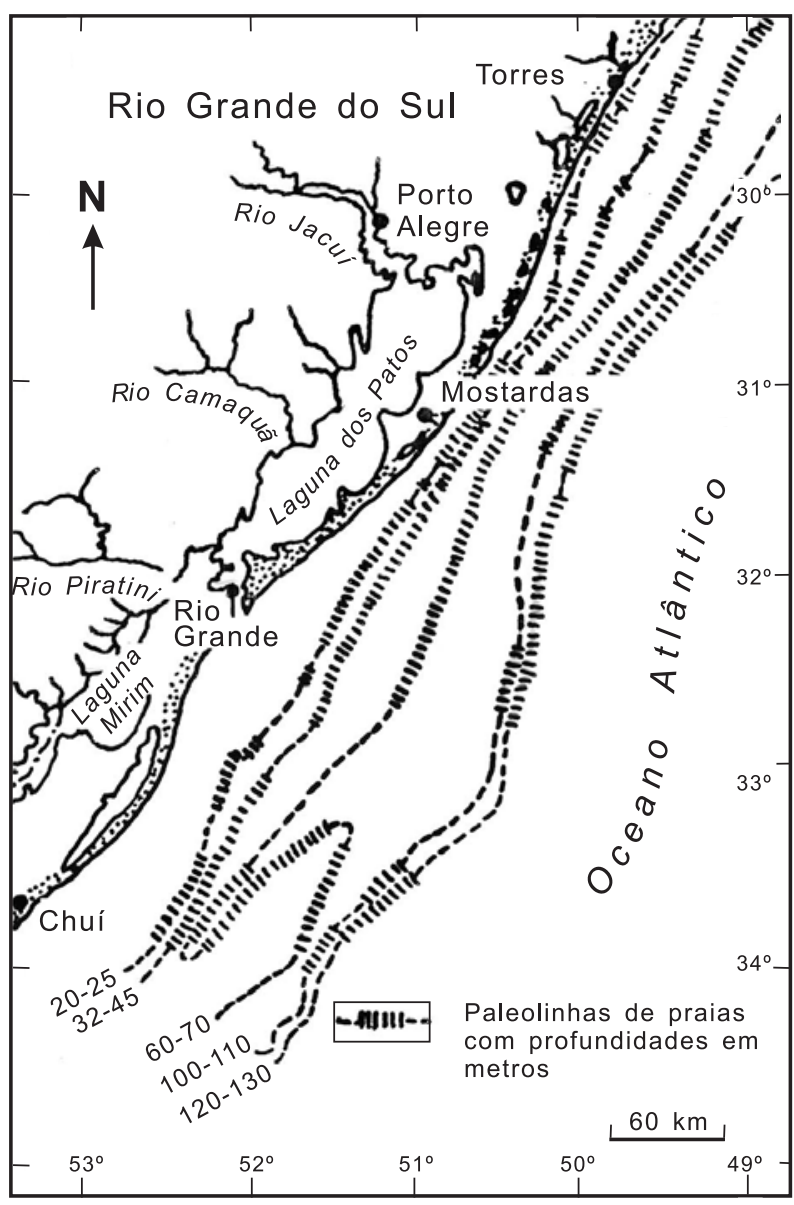

Figura 7. Mapa da plataforma continental do Rio Grande do Sul, mostrando os contornos das antigas linhas de praia, desenvolvidas nas fases de estabilização dos níveis do mar entre 17.500 e 6.500 AP (Corrêa, 1996).

tais média e externa, recobrindo a superfície erosiva desenvolvida sobre os depósitos subjacentes. Isto mostra que houve retrabalhamento de sedimentos mais antigos, na plataforma continental interna, durante as estabilizações do período transgressivo. Nesta fase, foram observadas escarpas provocando quebras nos declives entre 80 a 90 m e 60 a $70 \mathrm{~m}$.

O nível de 60 a $70 \mathrm{~m}$, segundo informações fornecidas por microorganismos, corresponderia ao início do Holoceno há aproximadamente 10.000 anos AP, quando o clima tornou-se mais ameno e houve aceleração na ascensão do nível relativo do mar.

c) Terceira fase (de 11.000 a 6.500 anos $A P$ ) - nesta fase, a velocidade de subida do nível do mar passou de cerca de 0,6 cm/ano para 1,6 cm/ano, comportando duas fases de estabilização entre 32 a $45 \mathrm{~m}$ e entre 20 a $25 \mathrm{~m}$.
Os sedimentos finos que, na época, eram transportados pelas drenagens fluviais para a zona litorânea, foram depositados além das zonas mais profundas da plataforma continental. Enquanto isso, os depósitos costeiros eram formados pelo retrabalhamento das areias transgressivas de idade pleistocênica.

À medida que o processo transgressivo continuava e a linha costeira se deslocava para oeste, os sedimentos finos recobriram as areias transgressivas das plataformas continentais média e externa. A presença de fases de estabilização é denunciada pelas camadas de cascalhos biodetríticos e concentrações de minerais pesados indicativas de antigas linhas de praia.

A plataforma continental do Rio Grande do Sul é provavelmente a mais detalhadamente estudada, em termos de níveis relativos do mar abaixo do atual, ao longo da costa brasileira. Além disso, na maior parte do litoral brasileiro pode-se dizer que a evolução do nível do mar, abaixo do atual, foi bastante semelhante à acima descrita.

\section{II.2.2.2. Evidências de níveis relativos do mar acima do atual}

Os indicadores desses eventos, reconhecidos nas planícies costeiras, foram reunidos em três grupos seguintes:

a) Indicadores geológicos - entre esses indicadores podem ser mencionados os terraços de construção marinha (wave-built terraces), os terraços de abrasão mari$n h a$ (wave-cut terraces) e as rochas praiais (beach rocks).

Os depósitos sedimentares marinhos, como os terraços de construção marinha, situados acima do atual nível do mar formando parte das planícies costeiras ou baixadas litorâneas, são evidências inquestionáveis de antigos níveis do mar acima do atual. O mapeamento geológico sistemático e as datações geocronológicas permitiram distinguir várias gerações de terraços arenosos, construídos após os níveis máximos relacionados a diferentes episódios transgressivos do Quaternário (Martin et al., 1987a 1988b).

Os terraços de abrasão marinha representam superfícies erosivas sustentadas por rochas mais antigas do embasamento, que podem ser sedimentares ou cristalinas (ígneas ou metamórficas). De maneira análoga aos terraços de construção marinha, eles são originados pela energia das ondas que, inicialmente, podem começar como entalhes marinhos (marine notches) de reduzidas dimen- 


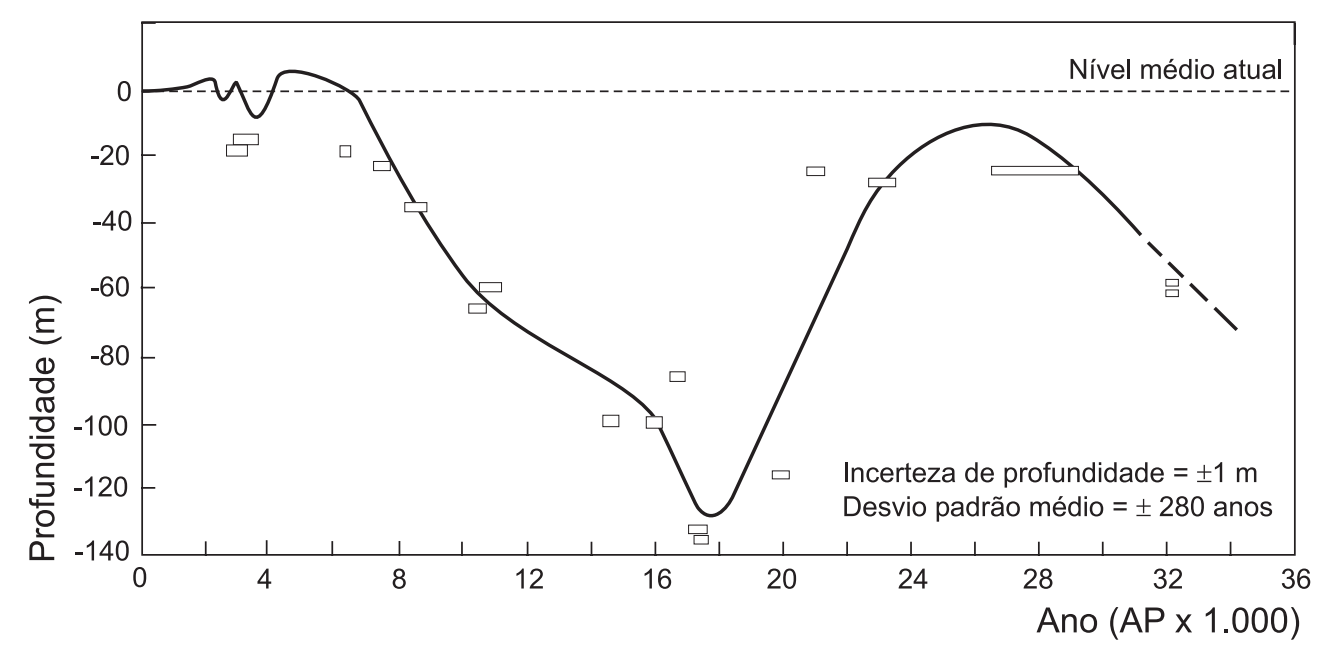

Figura 8. Curva de variações do nível relativo do mar desde cerca de 30.000 anos passados até hoje, segundo dados obtidos na plataforma continental e na planície costeira do Rio Grande do Sul (Corrêa, 1990).

sões, que aumentam de tamanho e podem progredir até cavernas marinhas (sea caves) e, finalmente, com o colapso dos tetos das cavernas acabam transformando-se em terraços de abrasão marinha.

As rochas praiais são constituídas de sedimentos arenosos ou cascalhosos de antigas praias, em geral cimentadas por $\mathrm{CaCO}_{3}$, contendo quantidades variáveis de conchas de moluscos e outros fragmentos biodetríticos, tais como, espinhos de ouriços, algas calcárias etc. Essas rochas são típicas de regiões de climas quentes e, ao longo do litoral brasileiro, são encontradas do litoral norte do Rio de Janeiro (complexo deltaico do Rio Paraíba do Sul) para o norte, principalmente na costa nordestina (Flexor \& Martin, 1979). Um estudo detalhado da granulometria e das estruturas sedimentares primárias dessas rochas pode fornecer indicações sobre os subambientes praiais onde foram sedimentadas e, desta maneira, definir com precisão de $50 \mathrm{~cm}$ a posição do nível médio do mar por ocasião da sua deposição.

b) Indicadores biológicos - são representados por restos biogênicos (origem orgânica ligada a animais ou vegetais), colônias ou traços fossilizados identificáveis de seres vivos, que são encontrados nas vizinhanças imediatas do nível do mar atual. Idealmente, esses indicadores devem corresponder a restos de organismos com distribuição vertical bastante restrita em vida, de modo que permitam obter a posição do nível do mar ou, mais precisamente, reconstruir a zonação dos organismos litorâneos relacionados aos limites das faixas de distribuição (Martin et al., 1986a).

Geralmente, os indicadores biológicos são representados por restos de populações mortas, mas ainda in situ (biocenose), de animais sésseis (fixos) em paredões rochosos, que permitam reconstruir as condições do antigo ambiente, particularmente as profundidades da água em vida.

Ao longo do litoral brasileiro existem evidências biológicas, representadas por incrustacões de vermetídeos (moluscos gastrópodes), ostras e corais, além de tocas (buracos) de ouriços (Fig. 9), acima da atual zona de vida desses organismos (Laborel, 1979). Além disso, muitos desses indicadores fornecem os materiais carbonáticos de suas conchas (carapaças), que podem ser datadas pelo método do radiocarbono (carbono 14).

Onde ocorre areia em contato com rocha, podem ser encontradas importantes estruturas devidas ao anelídeo (verme) do gênero Phragmatopoma. Esses animais usam os grãos de areia para construir os seus tubos, que formam massas arredondadas de até cerca de $1 \mathrm{~m}$ de diâmetro. Eles vivem em águas pouco profundas e o seu limite superior de vida corresponde mais ou menos à mesma altura do limite inferior de vida dos vermetídeos. Desde modo, onde só ocorrem tubos de vermetídeos não-viventes, como acontece ao sul de Cabo Frio (RJ) até o Cabo de Santa Marta Grande (SC), as posições relativas das amostras de 
vermetídeos em confronto aos níveis do mar, quando ainda viventes, podem ser obtidas da comparação com as posições das estruturas de Phragmatopoma vivente no local (Angulo et al., 1999).

Por outro lado, muitos terraços de construção marinha holocênicos e pleistocênicos exibem comumente tubos fósseis de Callichirus (popularmente conhecido por "corrupto"), situados acima da zona de vida deste animal (Suguio \& Martin, 1976). O gênero Callichirus, anteriormente conhecido por Callianassa, é um crustáceo decápode marinho, sendo composto por quase 95 espécies distribuídas no mundo inteiro, entre as quais, Rodrigues (1966) identificou cinco espécies viventes na costa brasileira. Aparentemente, entre os tubos fósseis, são mais comuns os devidos às espécies $C$. major e C. mirim.

No caso dos paleomanguezais, representados por concentração de restos vegetais de gêneros típicos de plantas (Rhizophora mangle, Laguncularia racemosa, Avicennia tomentosa etc), podem ser reconhecidas duas zonas. A superior que é em geral muito rica em fragmentos de madeira e a inferior que é, sobretudo, lamosa. Pode-se estimar que, no primeiro caso, a deposição tenha ocorrido entre os níveis médio e de maré alta da época e que, no segundo caso, corresponda aos níveis entre o médio e de maré baixa.

c) Indicadores pré-históricos - na costa brasileira, os únicos vestígios arqueológicos utilizáveis nos estudos das variações dos níveis relativos do mar são representados pelos sambaquis, que se situam sobre substratos de composição e idade bem diferentes (Fig. 10). Os sambaquis são montes artificiais com até mais de $20 \mathrm{~m}$ de altura e diâmetros que podem chegar a algumas centenas de metros. São compostos predominantemente de conchas de moluscos, mas também podem conter restos de instrumentos líticos e objetos de adorno, além de ossadas de mamíferos e espinhas de peixes e até esqueletos humanos.

Em geral, os sambaquis fornecem somente informações
Figura 9. Zonação biológica de animais sésseis e de vegetais, que vivem no costão rochoso do nordeste brasileiro, exemplificado pelo caso de Gaibu, PE (Laborel, 1979).

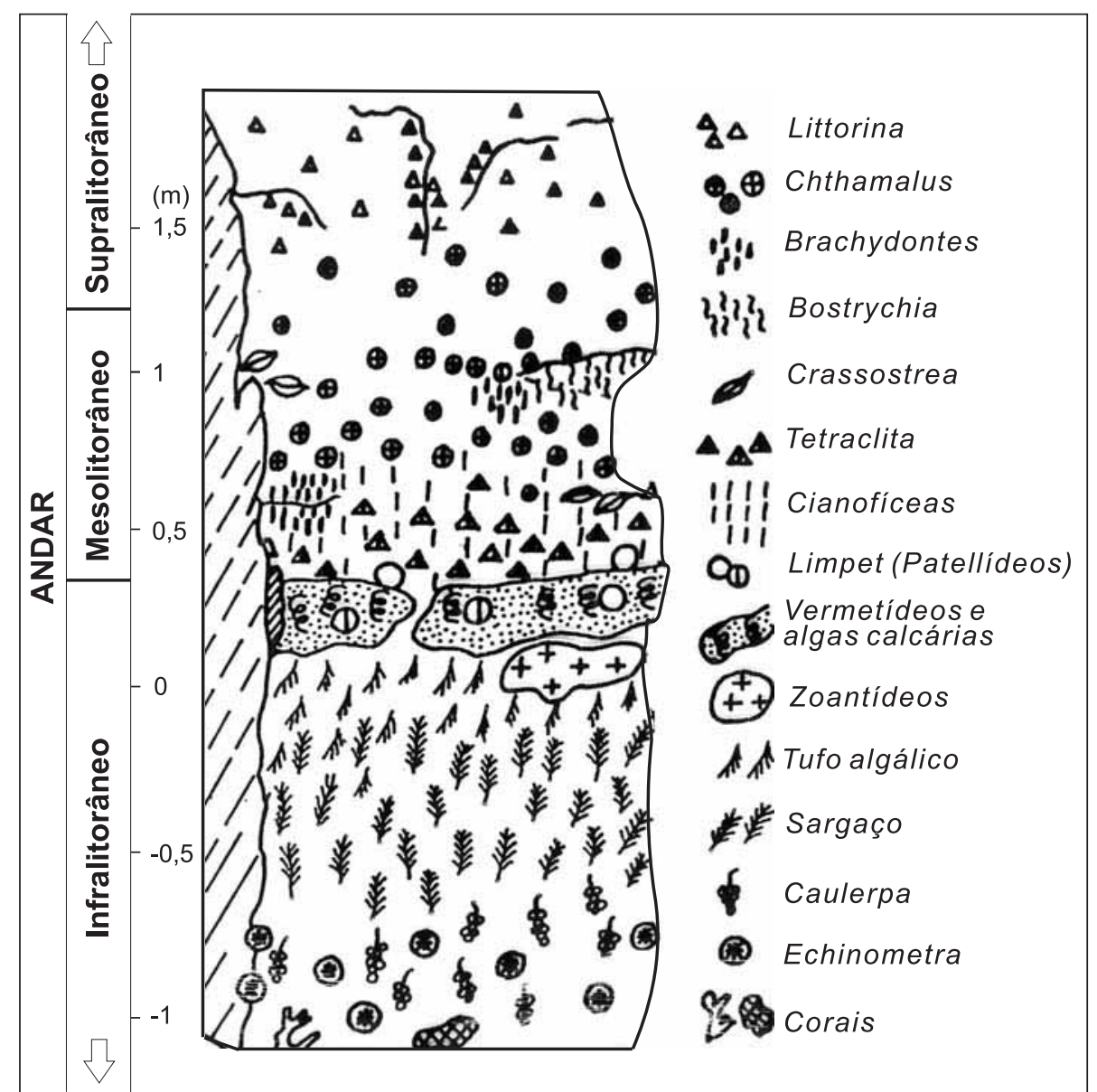


sobre a posição-limite da paleolinha de praia, podendo caracterizar períodos de nível do mar mais alto que o atual. Por exemplo, os sambaquis muito afastados da linha praial atual (20 a $30 \mathrm{~km}$ ou mais) no interior do continente e nas margens de paleolagunas sugerem periodos de nível do mar mais alto. Esta interpretação é baseada no postulado de que os antigos índios não tinham condições de transportar para longe dos locais de coleta, grandes quantidades de moluscos cujas conchas serviram para a construção dos sambaquis (Martin et al., 1986b; Suguio et al., 1992). Outra premissa que tem sido usada é de que, no início da construção dos sambaquis, o substrato estava emerso, isto é, encontrava-se acima do nível de maré alta da época. De qualquer modo, os dados obtidos dos sítios arqueológicos deverão ser necessariamente confrontados com indicadores geológicos e biológicos mais seguros e, então, serem utilizados com devido cuidado.

\subsubsection{Antigos níveis do mar, acima do atual, registrados na costa brasileira}

\section{II.2.3.1. Registros de níveis do mar anteriores a 123.000 anos AP}

Distribuídos através das planícies costeiras dos estados de Santa Catarina, Paraná e sul de São Paulo existem vestígios de terraços arenosos e cascalhosos com mais de $13 \mathrm{~m}$ de altura acima do nível do mar atual, de possível origem marinha. Segundo Martin et al. (1988b), este terraço poderia ser correlacionável ao sistema de ilhas barreira - lagunas II do Rio Grande do Sul (Fig. 11), onde são encontrados os registros mais completos desses eventos.

Nos estados da Bahia e Sergipe ainda não foram en-

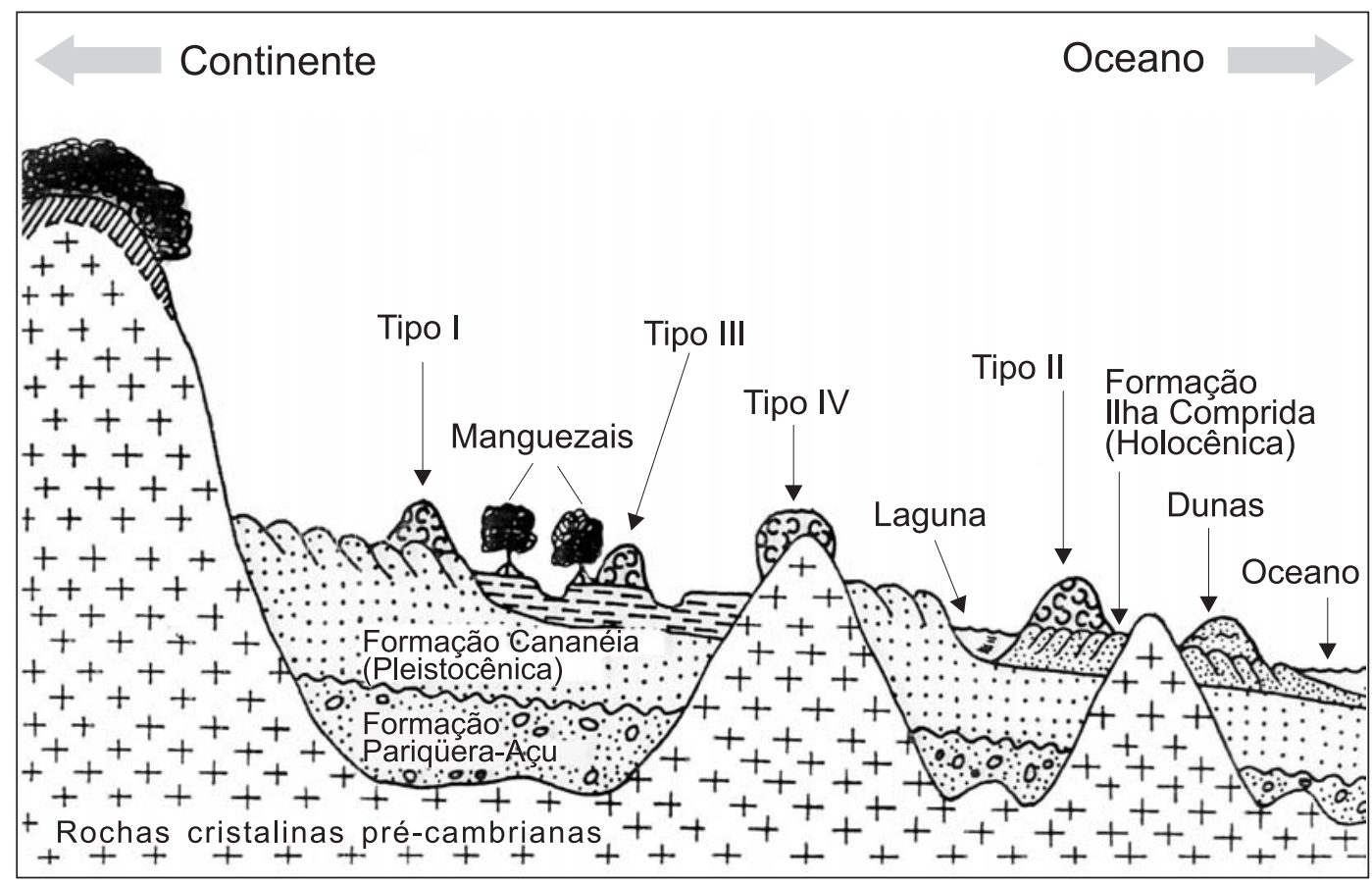

Figura 10. Tipos distintos de substratos, de diferentes composições e idades, dos sambaquis encontrados ao longo da costa brasileira (modif. de Fairbridge, 1976). 
contrados afloramentos de sedimentos que possam ser atribuídos a este episódio transgressivo. As únicas evidências conhecidas são falésias inativas (mortas), provavelmente de origem marinha, esculpidas em sedimentos da Formação Barreiras, de provável idade terciária. Este nível do mar mais alto anterior a 123.000 anos AP foi denominado de Transgressão Antiga (Bittencourt et al. 1979).

\section{II.2.3.2. Registros de níveis do mar mais altos que $O$ atual de 123.000 anos AP}

A Transgressão Antiga, acima referida, foi seguida por um novo evento transgressivo mundialmente reconhecido, quando o nível relativo do mar em grande parte da costa brasileira (nordeste, oriental, sudeste e sul) esteve $8 \pm 2 \mathrm{~m}$ acima do atual. Este episódio é conhecido no Estado de São Paulo como Transgressão Cananeiense (Suguio \& Martin, 1978) ou como Penúltima Transgressão nas costas da Bahia, Sergipe, Alagoas e Pernambuco (Bittencourt etal. 1979).

Os registros deste nível do mar mais alto são essencialmente compostos por terraços arenosos que ocorrem, pelo menos, desde os estados da Paraíba ao Rio Grande do Sul. Os seus topos chegam 6 a $10 \mathrm{~m}$ acima do atual nível de maré alta. Acham-se situados em posições mais internas, em relação às holocênicas nas planícies costeiras. São freqüentemente representadas por areias finas mais ou menos lixiviadas, que podem gradar para areias acastanhadas a pretas impregnadas de ácidos orgânicos (húmicos e fúlvicos) e eventualmente algum hidróxido de ferro, em geral originado dos horizontes superiores. As estruturas sedimentares acham-se, muitas vezes, obliteradas por processos pedogenéticos. Entretanto, tubos fósseis de Callichirus, acham-se associados a estratificações planoparalelas horizontais e cruzadas na base desses terraços, permitindo reconstruir as posições pretéritas dos níveis relativos do mar no espaço, pois esses animais constroem os seus tubos na zona intermarés e nas proximidades do nível de maré baixa. As antigas cristas praiais (cordões litorâneos ou cordões arenosos), mais ou menos dissipadas por processos gravitacionais (rastejo etc) e intempéricos.

Embora estejam relativamente bem preservados nas costas sul e sudeste do Brasil, os afloramentos desta formação não fornecem, em geral, materiais apropriados para datações geocronológicas. Troncos de madeira carbonizados, coletados das camadas argilosos basais indicam idades superiores a 35.000 anos AP (limite do alcance do método do ${ }^{14} \mathrm{C}$ ). Por outro lado, não foram encontrados até o momento, conchas de moluscos nesses depósitos, mas somente moldes de conchas. Porém, a idade desta transgressão foi relativamente bem estabelecida em amostras de corais (Siderastrea), obtidas da porção basal deste terraço na planície costeira do Estado da Bahia.

Foi empregado o método do Io/U (Bernat et al., 1983), obtendo-se uma idade média de $123.500 \pm 5.700$ anos AP. Esses terraços são, portanto, correlacionáveis ao nível do mar mais alto do estádio interglacial Sangamoniano (América do Norte) ou Eemiano (Escandinávia) do Pleistoceno superior (Bloom et al., 1974; Chappell, 1983) e ao sistema de ilhas barreira - lagunas III do Rio Grande do Sul (Villwock et al., 1986).

\section{II.2.3.3. Registros de níveis do mar mais alto que o atual do Holoceno}

A última fase transgressiva, conhecida como Transgressão Santista, iniciou-se há cerca de 17.500 anos AP, conforme o item II.2.2.1 deste texto. Relativamente poucas datações são, até o momento, disponíveis entre $6.500 \mathrm{a}$ 7.000 anos AP. Entretanto, os últimos 6.500 anos desta transgressão são muito melhor conhecidos, através de várias evidências geológicas, biológicas e pré-históricas na porção central da costa brasileira, onde foram realizadas mais de 700 datações geocronológicas por ${ }^{14} \mathrm{C}$ (Suguio et al. 1985a; Martin et al., 1996). Esta transgressão foi, muitas vezes, referida na literatura geológica brasileira como Transgressão Flandriana, aliás, erroneamente, pois nos chamados Países Baixos o nível do mar teve comportamento bem diferente do Brasil, neste intervalo de tempo. Na planície costeira do Rio Grande do Sul é referida ao sistema de ilhas barreira - lagunas IV (Fig. 11).

Constituem terraços de construção marinha situados nas porções externas dos de idades pleistocênicas, sendo separados destes por depressões alongadas ocupadas por lamas paleolagunares, que são superpostas por depósitos paludiais. Os terraços holocênicos estão alçados 4 a $5 \mathrm{~m}$ acima do nível atual do mar nas suas porções internas e exibem suave declividade rumo ao oceano, sugerindo que a sua construção processou-se durante a descensão progressiva do nível do mar. Na superfície desses terraços são encontradas cristas praiais bem preservadas, em contraste com o que ocorre nos terraços pleistocênicos. As estruturas sedimentares são bem preservadas e são representadas por estratificações características das faces praiais. 


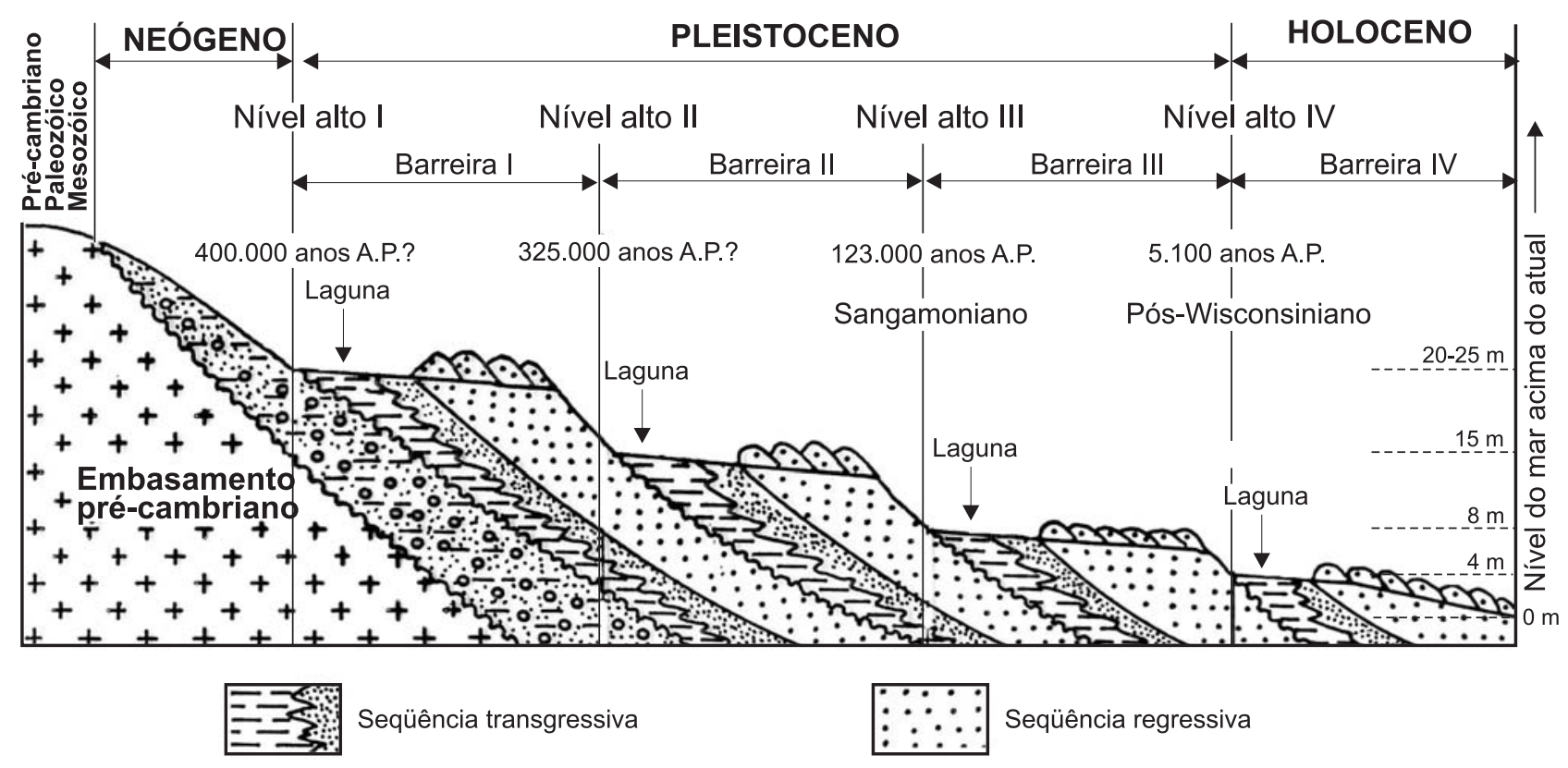

Figura 11. Quatro sistemas de ilhas barreira - lagunas registrados na planície costeira do Rio Grande do Sul, testemunhando fases de ascensão ao nível relativo do mar acima do atual no Quaternário (Villwock et al., 1986).

Os depósitos paleolagunares consistem de lamas ricas em matéria orgânica, com freqüentes restos de madeira e conchas de moluscos, alguns dos quais em posição de vida. As idades obtidas pelo método do radiocarbono, de afloramentos de terraços de construção marinha foram inferiores a cerca de 7.000 anos AP, exceto algumas amostras de depósitos paleolagunares obtidas por sondagens que forneceram idades pouco mais antigas.

\subsubsection{Curvas de variação dos níveis relativos do mar nos últimos 7.000 anos}

Com base em dados obtidos dos terraços holocênicos e de outros indicadores, evidenciando paleoníveis do mar diferentes do atual, foram esboçadas curvas parciais ou completas das flutuações dos níveis relativos do mar nos últimos 7.000 anos, em vários trechos do litoral brasileiro (Fig. 12).

Para que cada curva abrangesse somente trechos de comportamentos geológicos uniformes, principalmente em termos morfoestruturais, foram levados em conta trechos relativamente curtos (60 a $80 \mathrm{~km}$ ), que ainda apresentassem número suficiente (20 a 30) de indicadores datados. Abstraindo-se as variações de segunda ordem, foi possível constatar que em todos os setores estudados os níveis relativos do mar estiveram situados acima do atual, com as seguintes peculiaridades:

a) o nível médio atual do mar foi ultrapassado, pela primeira vez, entre 7.000 e 6.500 anos AP;

b) há cerca de 5.100 anos AP o nível do mar subiu entre 3 a $5 \mathrm{~m}$ acima do atual;

c) há cerca de 3.900 anos AP o nível relativo do mar deve ter estado 1,5 a $2 \mathrm{~m}$ abaixo do atual (Massad et al., 1996);

d) há aproximadamente 3.000 anos AP o nível do mar ascendeu entre 2 a 3,5 $\mathrm{m}$ acima do atual;

e) há 2.800 anos AP ocorreu novamente uma pequena descensão, atingindo provavelmente um nível inferior ao atual;

f) há cerca de 2.500 anos AP foi atingido um nível 1,5 a 2,5 m acima do atual e, desde então, tem ocorrido uma 

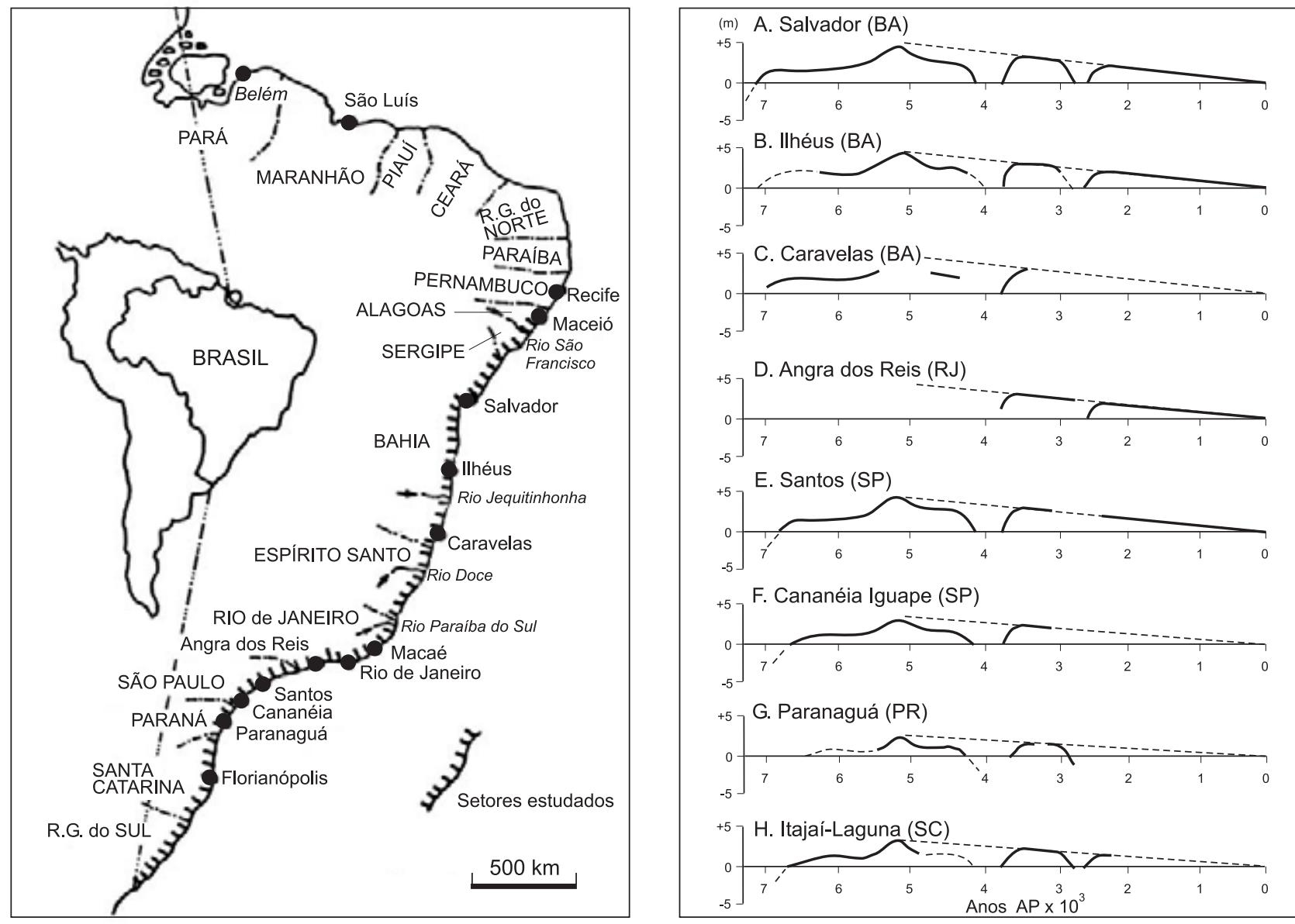

Figura 12. Curvas de variações dos níveis relativos do mar nos últimos 7.000 anos ao longo de vários trechos do litoral brasileiro (Suguio et al., 1985).

tendência ao rebaixamento contínuo, mas sendo o alcance mínimo do método do ${ }^{14} \mathrm{C}$ de cerca de 300 anos, não se pode determinar a tendência das últimas centenas ou dezenas de anos por métodos geológicos.

Entretanto, segundo Mesquita (1994), os dados baseados em registros instrumentais (maregramas) indicaram que, nos últimos 40 anos, estaria ocorrendo uma ascensão de nível de $30 \mathrm{~cm} /$ século na região de Cananéia (SP), cifra esta que é bem superior aos valores encontrados no hemisfério norte, abrangendo um tempo mais longo de medições (mais de 100 anos), de 10 a $15 \mathrm{~cm} /$ século.

\section{I.2.5. Algumas conseqüências das flutuações dos níveis relativos do mar na sedimentação costeira}

Em resumo, independentemente das causas, a porção central do litoral brasileiro esteve submetida à submersão até aproximadamente 5.100 anos AP e, ignorando-se duas rápidas oscilações negativas (de submersão), desde então permaneceu em emersão nos últimos 2.500 anos (Fig. 13). Entretanto, esta não é a regra geral para outras partes do mundo como, por exemplo, na costa atlântica dos Estados Unidos (Shepard \& Curray, 1967) ou até mesmo em alguns 
trechos da costa brasileira (Tomazelli et al., 1998).

Obviamente, a evolução geológica costeira durante os últimos anos não pode ter sido a mesma nessas duas áreas. Costa em submersão, como a porção oriental dos Estados Unidos é caracterizada por sistemas de ilhas barreira lagunas, enquanto que as em emersão, como extensas planícies de cristas praiais (Dominguez et al., 1987). Uma situação equivalente a encontrada atualmente na costa oriental dos Estados Unidos poderia ter existido no Brasil antes de 5.100 anos AP (Suguio et al., 1984).

Uma zona costeira baixa, de natureza arenosa, possui um perfil de equilíbrio que depende das características hidrodinâmicas e de granulação das areias. As características hidrodinâmicas dependem das ondas, marés etc e, portanto, o perfil está sofrendo constantes transformações. Entretanto, considerando-se um intervalo de tempo suficientemente longo, pode-se admitir a existência de um perfil médio de equilíbrio. É bastante óbvio que as variações dos níveis relativos do mar venham a destruir este perfil de equilíbrio.

Segundo Bruun (1962), quando um perfil de equilíbrio é atingido, a subseqüente ascensão do nível do mar destruirá este equilíbrio, que será restabelecido pela sua migração rumo ao continente. Conseqüentemente, o prisma praial será erodido e o material resultante será transportado e depositado nas áreas de antepraia, causando retrogradação. Este processo induzirá uma elevação do nível do mar, de modo que a profundidade da água permanecerá constante (Fig. 14).

Embora a regra acima tenha sido estabelecida para a situação inversa, isto é, de ascensão do nível relativo do mar, o equilíbrio destruído durante a descensão também deverá ser restaurado (Dominguez, 1982). Portanto, as ondas deverão transportar os sedimentos inconsolidados da antepraia rumo ao continente, depositando-os no prisma praial e promovendo a progradação costeira. Esta transferência de sedimentos da praia externa rumo ao prisma praial deverá cessar quando a profundidade preexistente tiver sido restabelecida.

Deste modo, é óbvio que em costas baixas arenosas, a descensão do nível relativo do mar induzirá intenso transporte de areia da plataforma continental interna para a praia.

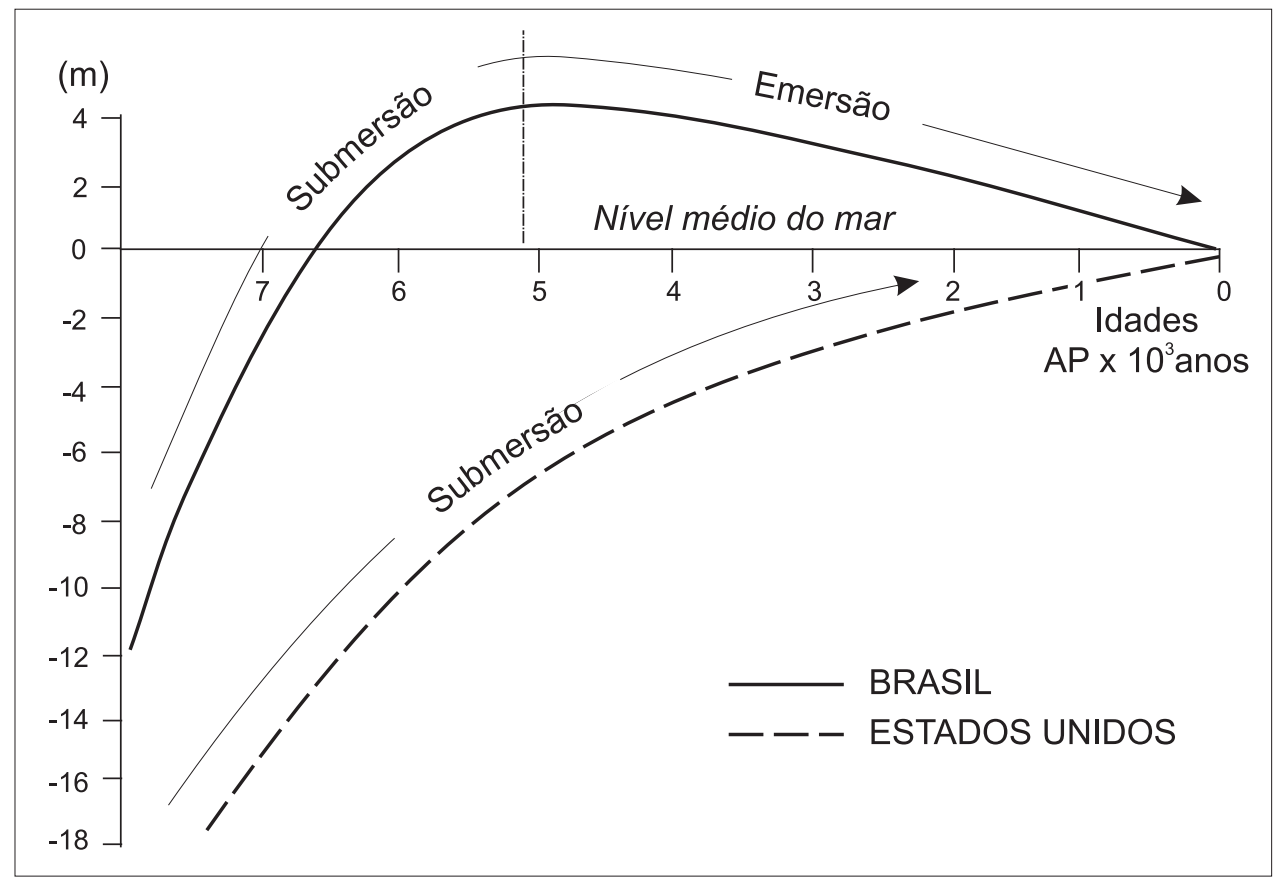

Figura 13. Curvas esquemáticas médias de variações dos níveis relativos do mar ao longo da costa central brasileira e ao longo das costas Atlântica e do Golfo do México dos Estados Unidos, durante os últimos 7.000 anos (Suguio et al., 1984). 
Estas areias serão incorporadas ao sistema de correntes longitudinais geradas pelas ondas e serão transportadas até encontrarem armadilhas (ou trapas) ao longo da costa, tais como, desembocaduras fluviais ou outras feições que diminuirão a capacidade de transporte do sistema de correntes longitudinais (ou de deriva litorânea).

\section{II.2.6. Papel do transporte longitudinal de areia na sedimentação costeira}

Nas proximidades das praias, as ondas não encontram profundidades de água suficientes ao seu avanço e sofrem arrebentação. Este fenômeno é acompanhado pela liberação de muita energia que será, em parte, usada para colocar os sedimentos em suspensão e também para gerar as correntes litorâneas longitudinais.

Obviamente as correntes litorâneas longitudinais são ativas somente quando as frentes de onda aproximam-se obliquamente à linha de costa. Por outro lado, os sentidos dessas correntes dependerão dos ângulos de incidência das frentes de onda que atingem a linha de costa. As velocidades dessas correntes são muito lentas, mas a sua influência é bastante efetiva onde as areias tenham sido colocadas em suspensão pela quebra das ondas e, portanto, volume muito significativo de areias poderá ser transportado desta maneira.

$\mathrm{O}$ transporte deverá prosseguir até que as areias sejam bloqueadas por uma armadilha ou por um obstáculo. Isto explica, em parte, as grandes diferenças que podem ser encontradas entre duas regiões que tenham sido submetidas a rebaixamentos equivalentes de níveis do mar. Os depósitos arenosos são insignificantes ou mesmo inexistentes em regiões de trânsito e muito conspícuos e abundantes onde uma trapa ou um obstáculo cause a retenção das areias. Além disso, em costas submetidas a dois diferentes padrões de ondulações, as mais efetivas são aquelas que definem o sentido de transporte resultante, que não coincidirá necessariamente com as ondulações mais freqüentes.

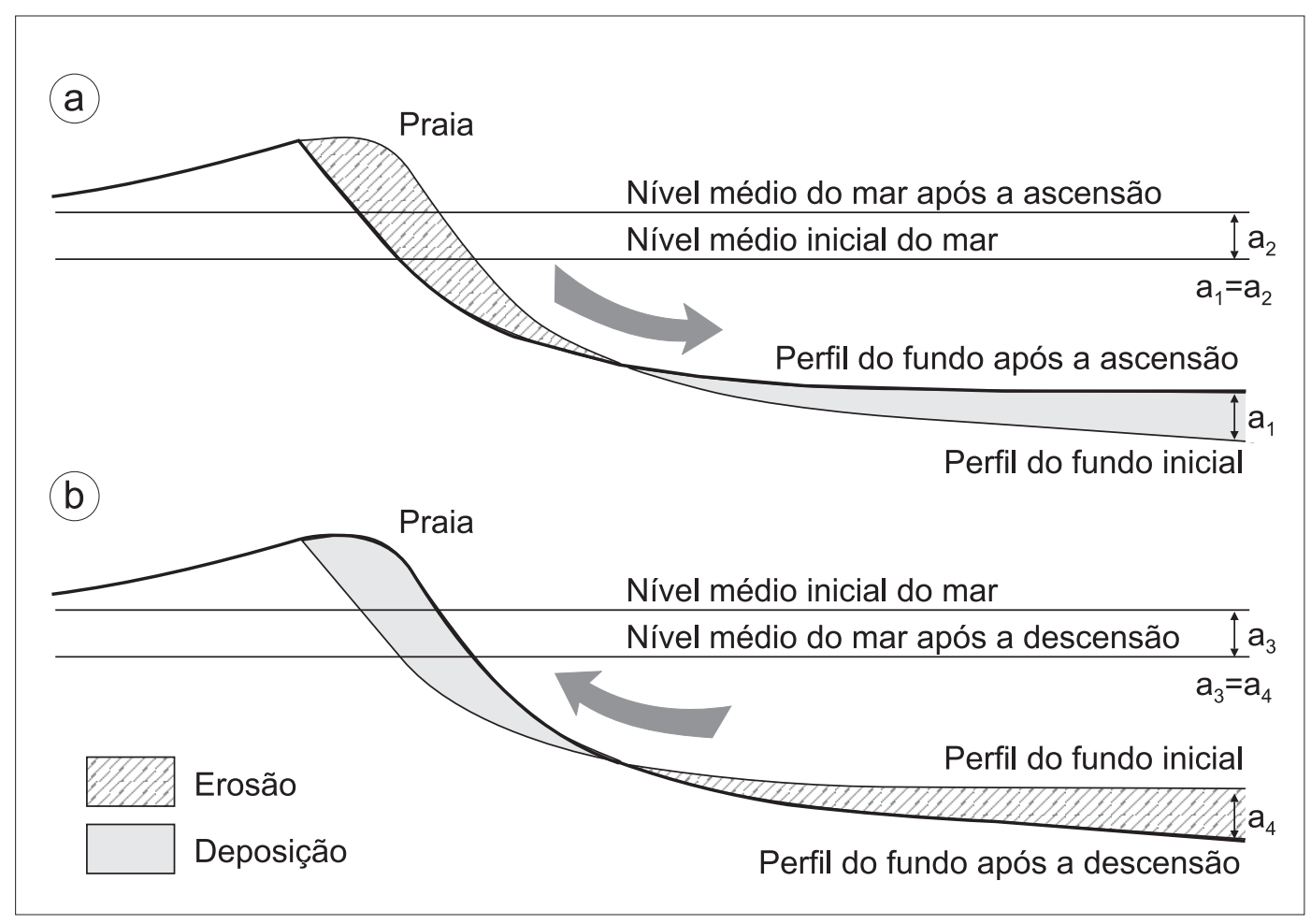

Figura 14. Princípio de Bruun (1962), segundo o qual o perfil médio de equilíbrio atingido em determinado nível do mar é rompido pela ascensão do nível relativo, provocando a retrogradação (a) e o inverso, quando ocorre a descensão do nível relativo, ocasionando a progradação (b), segundo Dominguez (1982). 


\section{II.2.6.1. O bloqueio do transporte longitudinal por uma desembocadura fluvial}

Em condições favoráveis, o fluxo de água de uma desembocadura fluvial pode bloquear o transporte de areia, de modo análogo a um espigão (ou molhe) artificial construído perpendicularmente a uma praia. Estas estruturas estendem-se, em geral, até além da zona de quebra das ondas, interrompendo o transporte litorâneo de areia. Em conseqüência, as linhas costeiras a barlamar serão submetidas à rápida progradação, enquanto a sotamar serão erodidas causando acelerada retrogradação. Os mecanismos ativos em uma desembocadura fluvial foram explicados por Dominguez (1982) e Suguio et al. (1985b) da seguinte maneira (Fig. 15):

a) em fase de enchente, o fluxo fluvial atua como um espigão hidráulico, tendendo a bloquear o transporte litorâneo. Este fato provoca a progradação de areia marinha na porção a barlamar $e$ retrogradação ou deposição de sedimentos fluviais a sotamar;

b) em fase subseqüente, de vazante, o obstáculo formado pelo fluxo fluvial tenderá a desaparecer. As correntes longitudinais, então causam erosão parcial dos depósitos marinhos e constroem um esporão arenoso (sand spit), que tenderá a obstruir parcialmente a desembocadura fluvial;

c) se a fase de vazante for suficientemente longa, o esporão arenoso crescerá e poderá resistir à fase seguinte de alta

Figura 15. Diagrama esquemático do processo de bloqueio de transporte litorâneo por fluxo fluvial (fases a-d), exemplificado pelo caso da planície costeira da desembocadura do Rio Paraíba do Sul (Suguio et al., 1985b). energia. Em alguns casos, somente a porção mais distal do esporão arenoso será destruída. Com isto o efeito de bloqueio do fluxo fluvial será deslocado no mesmo sentido das correntes longitudinais, iniciando-se uma nova fase de progradação a barlamar.

Como conseqüência do efeito de molhe do espigão hidráulico, as planícies costeiras em ambas as margens da desembocadura fluvial tornam-se assimétricas, com a porção a barlamar formada por uma sucessão de cristas praiais arenosas e a porção a sotamar composta por uma alternância de cristas praiais arenosas e baixios areno-argilosos. Os deslocamentos, controlados pela desembocadura fluvial, são registrados como discordâncias nos alinhamentos das cristas praiais arenosas. Este tipo de me-
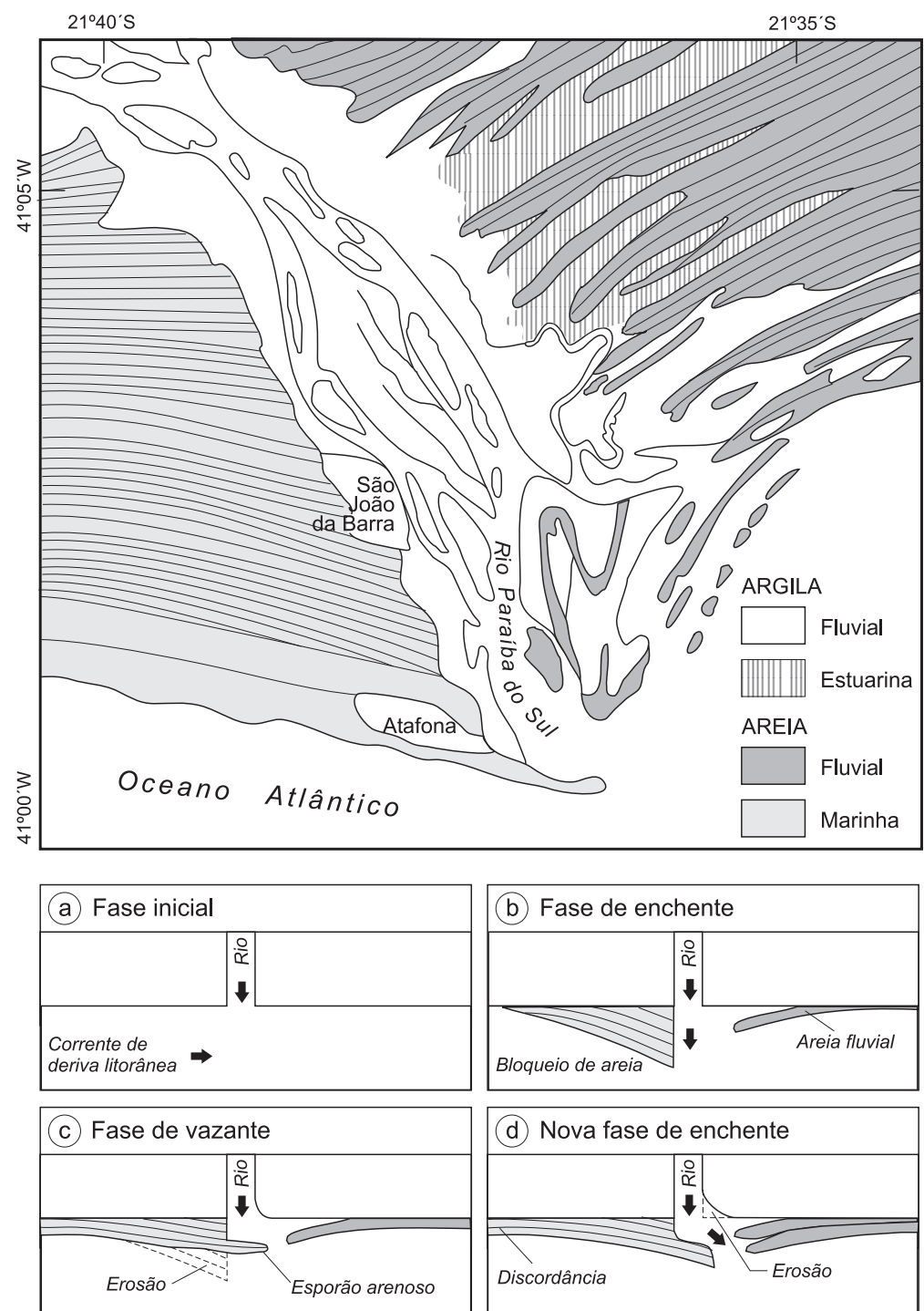
canismo é bastante evidente na planície costeira junto à desembocadura fluvial do Rio Paraíba do Sul (RJ). Como resultado, a vila de Atafona enfrenta periodicamente processos de erosão acelerada, que causam a retrogradação da costa e a destruição de dezenas de casas.

\section{II.2.6.2. Padrões de sistemas de ondulações ao longo da costa central brasileira}

Os padrões de sistemas de ondulações atuantes neste setor da costa brasileira ainda não são bem conhecidos, mas existem informações suficientes que permitem identificar pelo menos dois regimes de ondulações, correspondentes aos sistemas de ventos encontrados na área: o primeiro proveniente de ENE e o outro do SSE (Fig. 16).

Os de ENE são relacionados aos ventos alísios constantes, que atuam durante o ano inteiro, principalmente de outubro a março, enquanto que os de SSE são ligados às "frentes frias", que atingem periodicamente a costa central brasileira, principalmente de abril a setembro. Sobre o mar, as "frentes frias", são acompanhadas por ondulações provenientes do setor sul, que apesar da sua baixa freqüência, são muito mais poderosas que as originárias do setor norte e, conseqüentemente, o transporte longitudinal predominante processa-se do sul para o norte (Fig. 16A).

Entretanto, este modelo pode ser perturbado por fortes eventos "El_Niño". Quando este fenômeno é acentuado, como aconteceu em 1983, o jato subtropical é intensificado e os sistemas frontais polares são bloqueados (Fig. 16B), conforme Kousky et al. (1984). Durante o período de bloqueio, os sistemas frontais permanecem por longo tempo no sul e sudeste do Brasil. Em conseqüência, as ondulações do setor sul, geradas pelos "sistemas frontais" não atingem a costa central brasileira. Nesta situação, as ondulações originárias do setor norte tornam-se efetivas, provocando a deriva longitudinal do norte para o sul (Martin et al., 1984b).
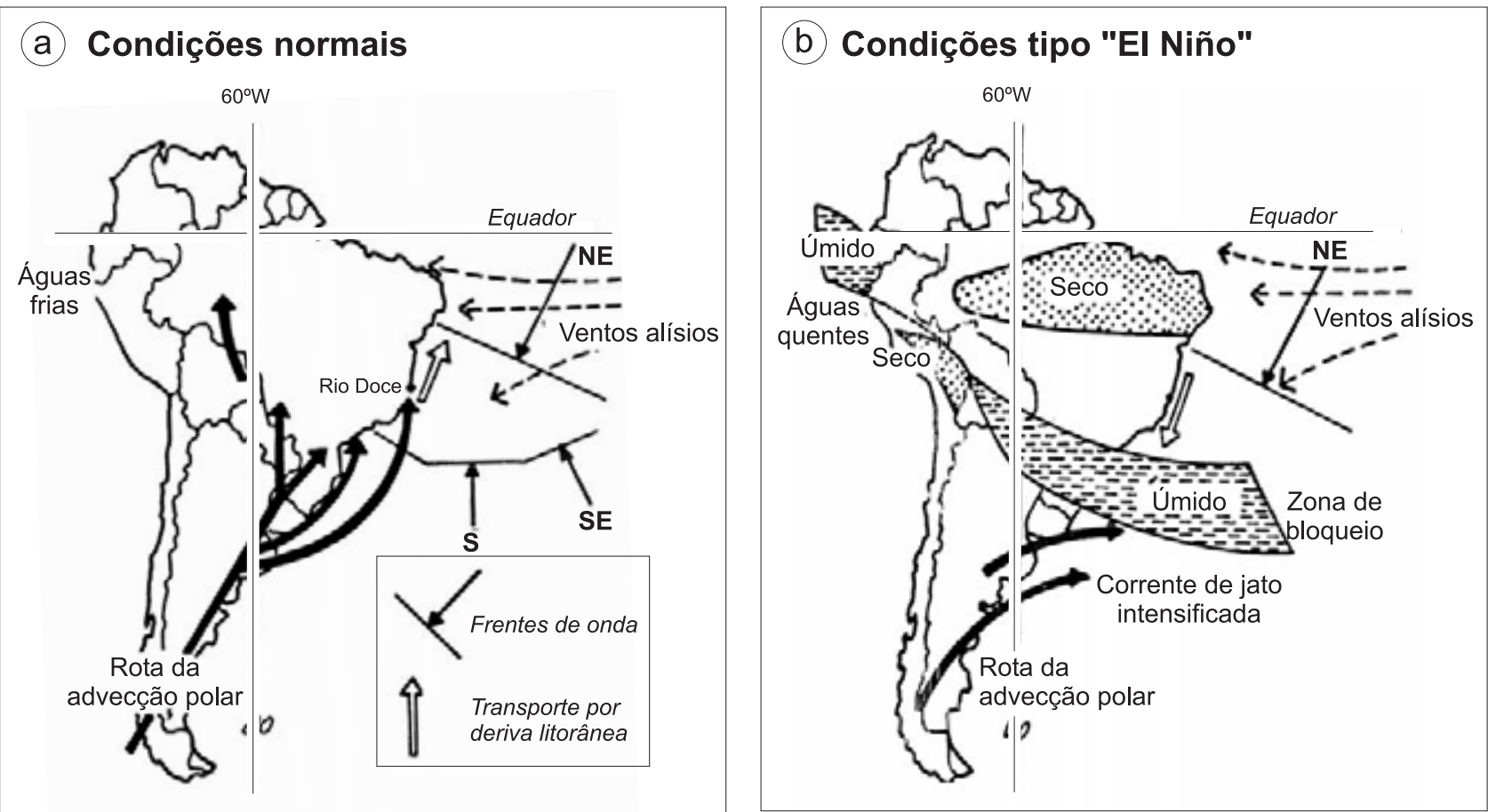

Figura 16. Padrões de circulação dos ventos na costa central brasileira e os sentidos de incidência das frentes de onda: (a) em condições normais, resultando no transporte litorâneo de areia do sul para o norte e (b) em condições "El Niño", resultando no transporte litorâneo de areias do norte para o sul (modif. de Martin \& Suguio, 1992). 


\section{II.2.7. Principais estágios de construção das planícies da costa central brasileira}

\section{II.2.7.1. Modelo geral}

As flutuações dos níveis relativos do mar e o transporte longitudinal de areia, associados com mudanças paleoclimáticas, controlaram esta construção. O modelo evolutivo mais completo foi estabelecido para a costa do Estado de Bahia (Dominguez et al., 1981). Este modelo permanece válido para o trecho do litoral brasileiro entre Macaé (RJ) e Recife (PE), cuja característica fundamental é a presença de "tabuleiros" terciários da Formação Barreiras, entre as planícies costeiras quaternárias e as serras pré-cambrianas compostas por rochas cristalinas (Martin et al., 1987a). Por outro lado, na metade sul da costa do Estado de São Paulo e ao longo das costas do Paraná e Santa Catarina este modelo é aplicável só parcialmente por razões locais (Martin et al., 1987b). Certamente, este modelo também não é aplicável na região amazônica, que é ainda muito pouco estudada (Souza Filho \& El-Robrini, 1997), não tendo sido esboçado qualquer modelo ou curva de variações de nível do mar.

$\mathrm{Na}$ costa do estado da Bahia puderam ser identificados os seguintes estágios (Fig. 17):

a) Estágio 1 (deposição dos sedimentos continentais da Formação Barreiras) - após um longo período de clima quente e úmido do fim do Terciário, que resultou na formação de um espesso manto de intemperismo (ou regolito), o clima tornou-se mais seco (talvez até semi-árido) com chuvas torrenciais e pouco freqüentes, ainda no Terciário, quando a vegetação tornou-se bem mais rarefeita e o regolito foi exposto à erosão. Os produtos de erosão foram transportados predominantemente por movimentos gravitacionais, depositando-se nos sopés das montanhas na forma de leques aluviais coalescentes (Fig. 17a). Segundo Bigarella \& Andrade (1964), o nível relativo do mar estaria muito abaixo do atual, permitindo que parte da plataforma continental fosse coberta por esses depósitos.

b) Estágio 2 (máximo da transgressão antiga) - o limite atingido pelo máximo desta transgressão é indicado por uma linha de falésias mortas (escarpas inativas) esculpidas nos sedimentos da Formação Barreiras (Fig. 17b), quando o clima teria sido mais úmido que na fase anterior; c) Estágio 3 (deposição dos sedimentos continentais pós-Barreiras) - após o máximo da transgressão e durante a regressão subseqüente, o clima readquiriu as características semi-áridas. Esta semi-aridez propiciou a sedimentação de novos leques aluviais coalescentes, que foram depositados nos sopés das escarpas esculpidas na Formação Barreiras durante o estágio 2 (Fig. 17c). Esses depósitos foram registrados nos estados da Bahia e Alagoas e, como eles parecem ter sido parcialmente erodidos durante o máximo da Penúltima Transgressão, devem ter uma idade mais antiga que 123.000 anos;

d) Estágio 4 (máximo da penúltima transgressão) - há cerca de 123.000 anos AP o nível relativo do mar estava $8 \pm 2 \mathrm{~m}$ acima do atual. Durante este episódio os sedimentos continentais depositados no estágio precedente foram parcialmente erodidos e os cursos inferiores dos rios foram afogados e transformados em estuários e lagunas (Fig. 17d);

e) Estágio 5 (construção de terraços marinhos pleistocênicos) - teve início uma nova fase regressiva, quando terraços arenosos cobertos por cristas praiais foram originados, formando-se extensas planícies costeiras (Fig. 17e). Durante esta descensão do nível relativo do mar, a plataforma continental atual ficou quase completamente exposta, estabelecendo-se então uma rede de drenagem, que acabou erodindo parte dos terraços marinhos construtivos, embora a superfície original de sedimentação tenha sido preservada nas áreas de interflúvios;

f) Estágio 6 (máximo da última transgressão) - entre cerca de 6.500 a 7.000 anos AP o nível relativo do mar chegou ao atual e, a seguir, passou por um máximo situado 4 a $5 \mathrm{~m}$ acima do atual há cerca de 5.100 anos AP. Durante esta transgressão os terraços pleistocênicos foram total ou parcialmente erodidos. Uma paisagem comum desta fase foi a formação de sistemas de ilhas barreira - lagunas (Fig. 17f), principalmente nas desembocaduras dos rios Doce, Paraíba do Sul etc;

g) Estágio 7 (construção de deltas intralagunares) quando um rio desemboca nessas lagunas, despejando suas águas e sedimentos, foram formados deltas intralagunares ou intraestuarinas, cujas dimensões dependem dos tamanhos das lagunas e dos rios (Fig. 17g);

h) Estágio 8 (construção de terraços marinhos holocênicos) - após 5.100 anos AP, o nível relativo do mar 


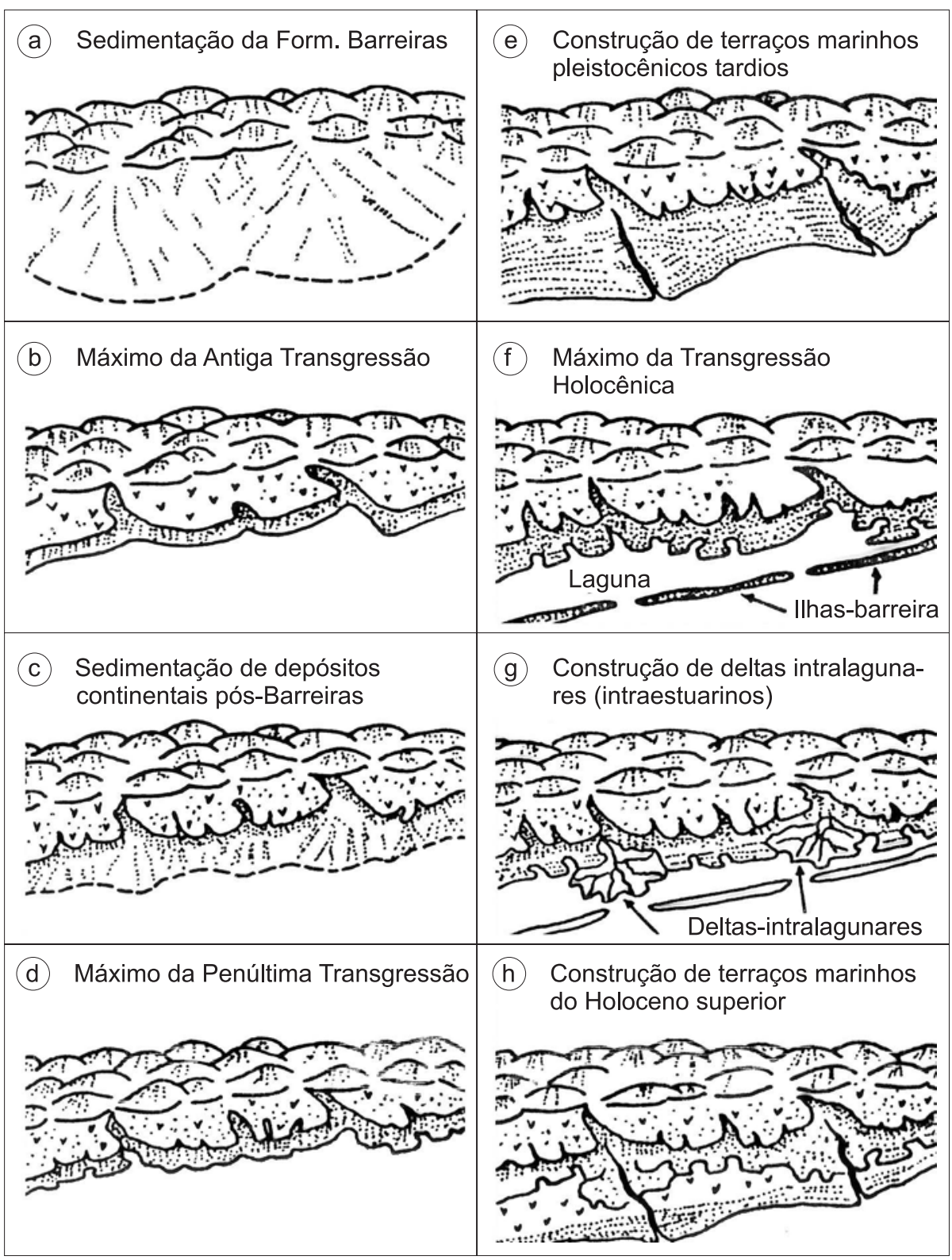

Figura 17. Modelo geral de evolução geológica das planícies costeiras da porção central do litoral brasileiro durante o Quaternário, válido para o trecho entre Macaé (RJ) e Recife (PE). 
sofreu descensão progressiva até a posição atual, não sem antes passar por duas rápidas fases de flutuações entre 4.100 a 3.600 anos AP e entre 3.000 a 2.500 anos AP. Durante os episódios de emersão ocorreu acreção de cristas praiais nas porções externas das ilhas-barreira (Fig. 17h). Em alguns casos, como na foz do Rio Jequitinhonha, foi possível reconhecer até três gerações de terraços holocênicos, correspondentes a três estágios de emersão posteriores a 5.100 anos AP (Dominguez, 1982). Concomitantemente à construção dos terraços marinhos, a descensão do nível relativo do mar causou uma gradual transformação de lagunas em lagos, seguidos de pântanos e, só então, os rios passaram a fluir diretamente aos oceanos.

\section{II.2.7.2. Casos especiais de planícies costeiras situadas nas desembocaduras de grandes rios}

Associadas às desembocaduras dos mais importantes rios brasileiros (Paraíba do Sul, Doce, Jequitinhonha e São Francisco) existem zonas de progradação, que foram classificados por Bacoccoli (1971) como "deltas altamente destrutivos dominados por ondas". Este autor admitiu que todos esses deltas seriam holocênicos e propôs um esquema evolutivo em que eles teriam sido formados após o máximo da Transgressão Flandriana (melhor seria Última Transgressão), passando em alguns casos por um estágio intermediário estuarino, para finalmente construir deltas típicos, que implicam na progradação generalizada da costa.

A maioria dos modelos de sedimentação costeira, até então existentes e considerados como clássicos, não avaliaram adequadamente o papel fundamental desempenhado pela história das flutuações do nível relativo do mar no desenvolvimento das atuais regiões costeiras. Por exemplo, o interessante trabalho de Coleman \& Wright (1975), embora tenha analisado as interferências de inúmeros parâmetros que influem na geometria dos corpos arenosos deltaicos, não considerou praticamente os efeitos das oscilações do nível relativo do mar no Holoceno. Os modelos de sedimentação costeira existentes, quase todos baseados em casos estudados no hemisfério norte, enfatizavam as amplitudes de marés, a energia das ondas e as descargas e cargas fluviais, como controles mais decisivos na definição do arcabouço geral dos ambientes de sedimentação costeiros (Fisher, 1969; Galloway, 1975; Hayes, 1979). Entretanto, embora esses fatores sejam tam- bém importantes, influem em geral só na morfologia costeira local. Na realidade, é a história das oscilações dos niveis do mar que determina o arcabouço básico, sobre o qual irão atuar todos os outros fatores mencionados.

Novos estudos detalhados executados nas planícies costeiras do Rio Paraíba do Sul (Martin et al., 1984a); Rio Doce (Suguio et al. 1982); Rio Jequitinhonha (Dominguez, 1982; Dominguez et al., 1987); Rio São Francisco (Bittencourt et al., 1982), sumariados por Martin et al. (1993), mostraram que as suas histórias holocênicas e também as pleistocênicas foram fortemente influenciadas pelas variações dos níveis relativos do mar. Finalmente, considerando-se a definição do termo "delta sensu strictu", essas zonas de progradação nem poderiam ser considerados como deltas, pois os seus sedimentos foram só parcialmente supridos diretamente pelos rios aos quais se acham associados, sendo o restante fornecido pelo ambiente marinho adjacente.

\section{II.2.7.3. Casos de planícies costeiras brasileiras ainda pouco estudadas}

As planícies costeiras ao norte do litoral do Estado da Bahia, principalmente a partir dos Estado da Paraíba, ainda não foram alvo de estudos sistemáticos quanto as suas evoluções geológicas. As únicas que foram estudadas, neste trecho, de modo mais ou menos sistemático são as planícies costeiras dos estados de Alagoas (Barbosa et al., 1987) e Pernambuco (Dominguez et al., 1990).

A planície costeira da foz do Rio Amazonas também é ainda relativamente pouco estudada neste contexto (Souza Filho, 1995; Souza Filho \& El-Robrini,1997), havendo mesmo controvérsias se deveria ser classificada como um estuário ou como um "delta altamente destrutivo denominado por marés". Um trabalho mais interessante, neste particular, foi publicado por Nittrouer et al. (1986), que caracterizaram a sedimentação da plataforma continental amazônica como de "natureza deltaica", também com frente progradante. Entretanto, ela diferiria fundamentalmente dos "deltas clássicos", podendo ser classificado mais como um estuário ou um "delta submerso", por exibir expressão subaérea negligenciável. Este fato poderia ser explicado, talvez, porque o Amazonas é um grande rio em zona dominada por macromarés, com carga sedimentar fantástica. Porém, ele deságua em oceano aberto com alta energia, tanto das ondas como de fortes correntes longitudinais de SE para NW, que, carregam grande parte dos sedimentos para longe da sua desembocadura. 


\section{AS REGIÕES LITORÂNEAS E O DESENVOLVIMENTO SUSTENTÁVEL}

\section{III.1. Generalidades}

As regiões litorâneas constituem os limites entre os continentes e os oceanos, sendo caracterizadas pela $n a-$ tureza geológica dos continentes (litologias e arcabouços tectônicos) e pela energia das ondas e dos ventos. Os ambientes litorâneos estão em constante mutação, pela ininterrupta procura de uma situação de equilíbrio através do confronto entre as diversas forças antagônicas aí atuantes. Portanto, os perigos enfrentados pelos habitantes das regiões litorâneas podem, até certo ponto, ser comparados aos existentes em uma planície fluvial devidos às freqüentes enchentes ou das cercanias de um vulcão ativo prestes a entrar em erupção, isto é, sempre sujeitos a uma eventual catástrofe, já pela potencialidade destas regiões a vários fenômenos naturais que causam transformações devidas às suscetibilidades naturais.

Entretanto, não há qualquer dúvida que as áreas litorâneas exercem um imenso fascínio, de modo que populações humanas tendem a aumentar a ocupação dessas áreas. Desta maneira, os fatores antrópicos superpõem-se às forças dinâmicas atuantes, exacerbando as suscetibilidades naturais e introduzindo suscetibilidades induzidas, criando situações de crises cada vez mais complexas de várias naturezas.

Quando o Homem ocupa e modifica o espaço físico, na busca incessante dos recursos naturais disponíveis e de situações mais convenientes a sua subsistência e bem estar, ignora as leis da natureza e introduz os fatores antrópicos. Esses fatores atuam, em geral, na intensificação dos "perigos naturais" preexistentes gerando novos perigos e, por outro lado, o Homem passa a arcar com o ônus das respostas do meio físico às intervenções realizadas. A presença do Homem constitui a razão da existência dos "perigos naturais" (natural hazards) e dos riscos, já que os fenômenos naturais constituem eventos normais e freqüentemente até previsíveis. Porém, a maior dificuldade no enfrentamento destas questões relacionase à ocupação indevida, de regiões com potenciais "perigos naturais”, muitas vezes por razões essencialmente políticas e /ou sócio-econômicas.

As áreas costeiras do Japão, por exemplo, que além de ser um dos países de maior densidade demográfica do mundo, são intensamente castigadas por uma impressionante plêiade de "perigos naturais", segundo a Fig. 18, teria somente 55,2\% do seu litoral em estado natural, enquanto $30,4 \%$ seriam completamente artificiais e 13,6\% semi-artificiais (Koike, 1996).

Portanto, para que o relacionamento do Homem com as áreas litorâneas ocorra de maneira menos impactante possivel e que o desenvolvimento seja sustentável, há urgente necessidade de conhecimentos cada vez mais aprofundados sobre os processos costeiros e também sobre os possíveis efeitos das atividades antrópicas.

\section{III.2. Situação das regiōes litorâneas brasileiras em relação aos "perigos naturais" e d̀ conservação de ecossistemas}

Em confronto com o Japão, as regiões litorâneas brasileiras apresentam-se em situação muito privilegiada! Dos sete tipos de "perigos naturais" enumerados por Koike (1996), praticamente só o de número 3, relacionado à erosão acelerada de praias e de falésias, constitui um problema mais sério em alguns trechos. Mesmo neste caso, pode-se considerar como uma suscetibilidade, na maioria das vezes, induzida pela ocupação humana inadequada do meio físico. Ao lado disso, podem ser considerados dois outros tipos de "perigos costeiros", devidos à suscetibilidade natural, que são os escorregamentos (movimentos gravitacionais) e as inundações. Os escorregamentos são característicos de regiões mais montanhosas de cidades como o Rio de Janeiro, Vitória e Santos, todas situadas no "litoral sudeste ou das escarpas cristalinas" de Silveira (1964). Entretanto, este fenômeno tem acontecido também nas bordas de "tabuleiros" da Formação Barreiras, com vertentes bastante íngremes, como nas cidades de Recife e Salvador. Por outro lado, todas as cidades situadas sobre as planícies costeiras são mais ou menos suscetíveis às inundações, cujos efeitos são exacerbados pelo adensamento populacional. Entretanto, o "litoral sudeste ou das escarpas cristalinas", freqüentemente caracterizado por acentuado contraste no relevo, que dificulta o escoamento das águas pluviais, constitui também causa de ocorrência de "chuvas orográficas" e de escorregamentos.

Deste modo, a seguir são descritos alguns dos problemas de natureza geocientífica, das regiões litorâneas, que eventualmente podem representar um óbice ao desenvolvimento sustentável. 


\section{III.3. Erosão acelerada de falésias marinhas}

As falésias marinhas constituem costas rochosas caracterizadas pela erosão devida à alta energia das ondas. Se por um lado, a erosão representa um fator negativo por causar retrogradação, por outro lado, pode ser considerado como um fator positivo na alimentação de praias adjacentes com sedimentos. Movimentos tectônicos ativos, como os que ocorrem na Califórnia (Estados Unidos) produzem costas rochosas como resultado de processos orogenéticos, associados à deformação de rochas por dobras e falhas. As falésias marinhas são também en- contradas em locais onde geleiras e fortes ondas removem os sedimentos mais finos como, por exemplo, em Maine e parte do Alasca (Estados Unidos), onde as geleiras erodiram completamente as coberturas sedimentares das áreas costeiras. No Oceano Ártico, a moagem e o arrastamento pelas geleiras também removeram as partículas arenosas das praias, deixando apenas calhaus e matacões na forma de depósitos residuais (lag deposits).

Ao longo do litoral japonês, segundo Koike (1997), da linha costeira de $19.000 \mathrm{~km}$ que circundam as quatro ilhas principais do arquipélago, $80 \%$ correspondem a costas rochosas com predominância de abrasão marinha por ondas (Fig. 19). Os segmentos de costas rochosas são interrompidos por numerosas praias-de-bolso ocupadas

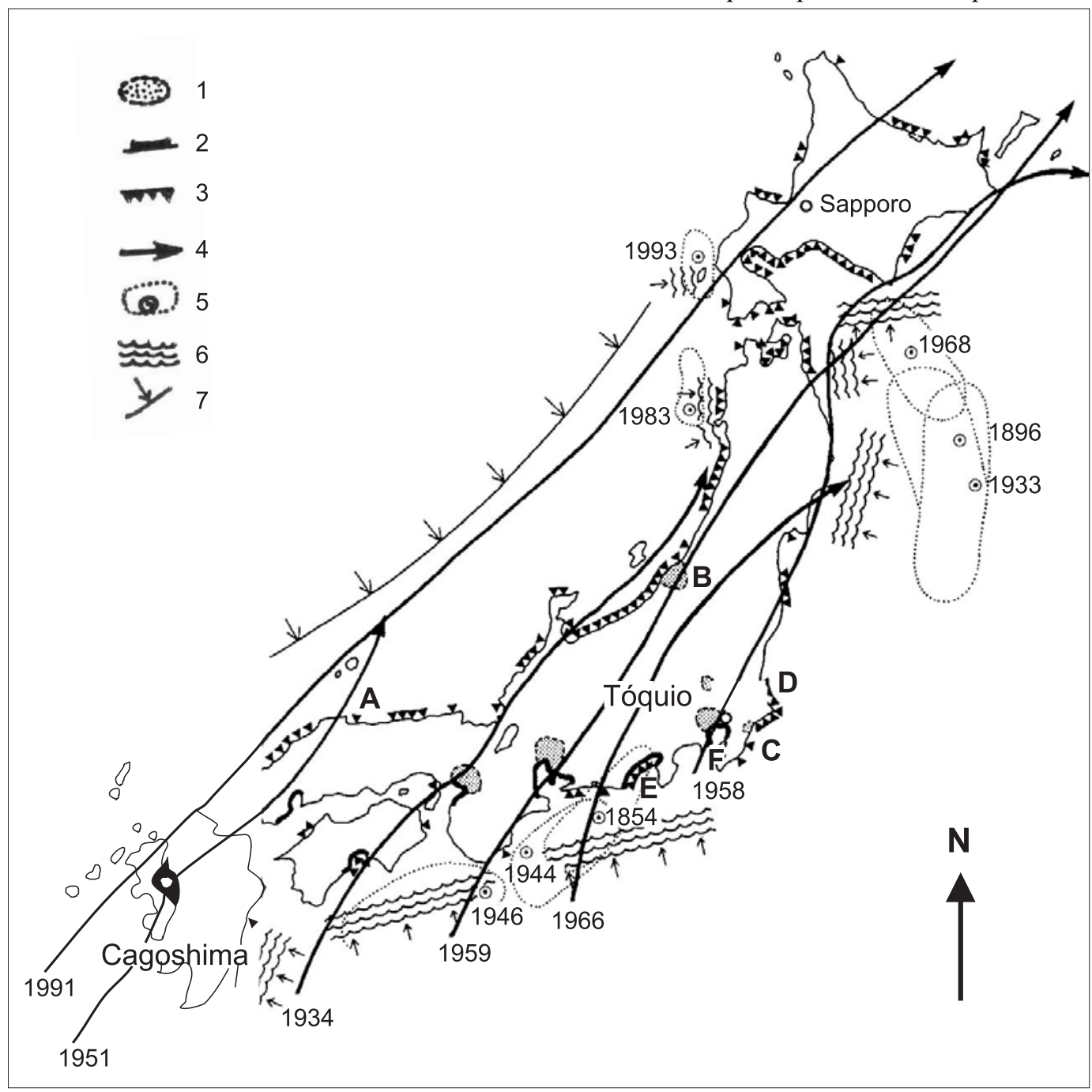

Figura 18. Características regionais dos perigos costeiros (coastal hazards) ao longo das ilhas japonesas, segundo várias fontes (Koike, 1996). 1) Áreas submetidas à severa subsidência do terreno; 2) Costas de baías perigosas pelas ondas de tempestade geradas por tufões; 3) Costas submetidas à severa erosão; 4) Rotas de passagem dos principais tufões; 5) Áreas de hipocentros e epicentros dos principais terremotos; 6) Tsunâmis (maremotos); 7) Monções de inverno. 
por areias e/ou cascalhos. Além disso, muitas das falésias são compostas de rochas vulcânicas ou sedimentares com idades variando de cretácicas a terciárias, em geral bastante suscetíveis à erosão (Koike, 1996). A erosão acelerada dessas falésias marinhas é, em parte, impedida pela construção de muros marinhos (seawalls) ou quebramares (breakwaters) ou, ainda, utilizando-se tetrápodes de concreto armado (Fig. 20).

Nas costas sudeste (desde Cabo Frio, RJ) e sul (até o Cabo de Santa Marta Grande, SC) são também freqüentes as falésias marinhas em rochas cristalinas (ígneas e metamórficas) pré-cambrianas. Em geral, essas rochas são bastante resistentes e, por não apresentarem problemas de erosão acelerada, não exigem medidas especiais de proteção.

Entretanto, nas costas oriental (desde a foz do Rio Paraíba do Sul), nordeste e norte são comuns as falésias marinhas esculpidas na Formação Barreiras. Esses sedimentos terciários, de origem essencialmente continental, são pouco consolidados e, portanto, extremamente suscetíveis à erosão marinha e a escorregamentos e outros movimentos de massa (Alheiros, 1995). Entretanto, devido à ocupação humana relativamente rarefeita nessas áreas, são poucas as estruturas de proteção que, quando existentes, são muito rudimentares.

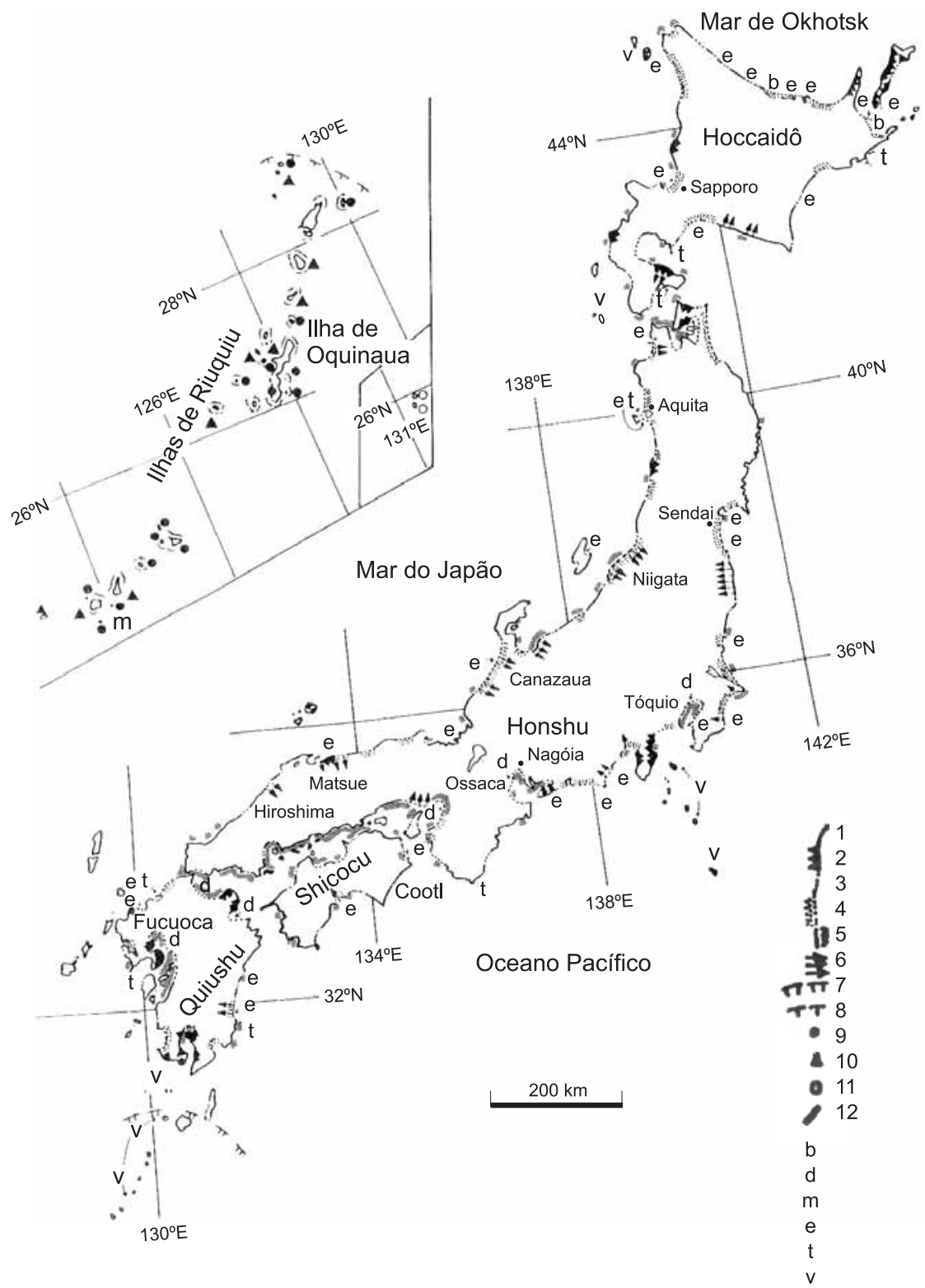

Figura 19. Diversos tipos de morfologias costeiras das ilhas japonesas: 1) Costas escarpadas; 2) Costas vulcânicas; 3) Costas arenosas; 4) Costas arenosas com dunas bem desenvolvidas; 5) Recifes de corais; 6) Costas submetidas à erosão severa; 7) Limite setentrional de crescimento de corais no Holoceno; 8) Limite setentrional de crescimento de corais no Pleistoceno; 9) Recifes de corais emersos formando topos de ilhas; 10) Recifes em frania emersos; 11) Recifes em atol emersos; 12) Costas antrópicas; b) Ilhas-barreira; d) Costas deltaicas; m) Manguezais; e) Esporões e barras; †) Tômbolos; v) Ilhas vulcânicas (Koike, 1997). 
Figura 20. Formas especiais de tetrápodes e outras estruturas, destinadas à absorção de parte da energia das ondas, para a proteção da zona costeira, em geral moldadas em concreto armado (Franco, 1993).

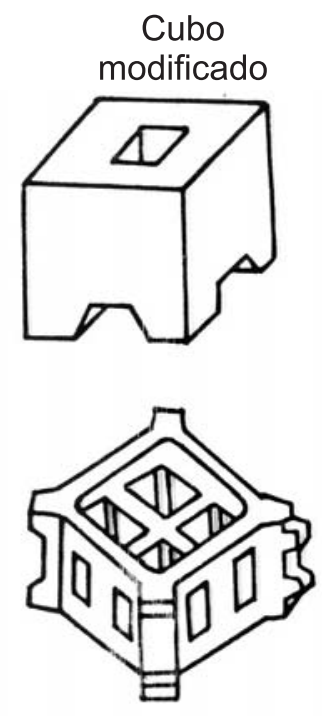

Diodo
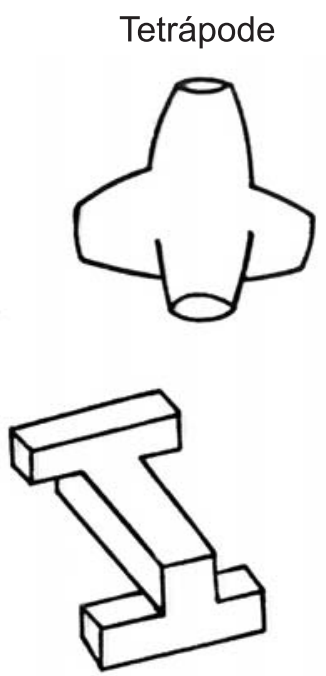

Bloco em "I"
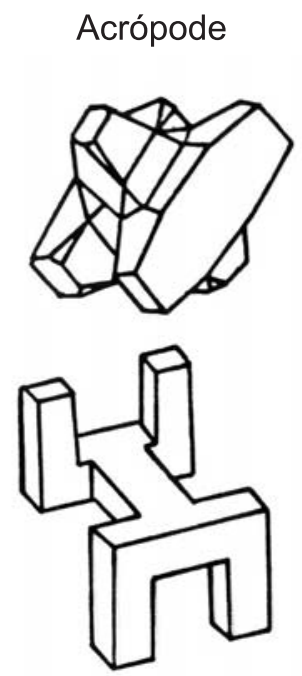

Bloco em "U" duplo

\section{III.4. Erosão acelerada de praias}

As praias podem ser arenosas ou cascalhosas. As do primeiro tipo são predominantes no litoral brasileiro, enquanto que as do segundo tipo são mais comuns em países como o Canadá, que foi severamente afetado pelas glaciações quaternárias.

A erosão praial é um dos fenômenos mais impressionantes entre os processos costeiros, que acabou transformando-se em um problema emergencial na maioria das áreas costeiras do mundo, inclusive em diversos trechos do litoral brasileiro. Segundo Bird (1985), mais de 70\% das costas arenosas do mundo têm exibido uma tendência erosiva nas últimas décadas, menos de $10 \%$ apresentaram progradação e 20 a $30 \%$ mostraram-se mais ou menos estáveis ou sofreram transformações quase imperceptíveis no mesmo período de tempo. Esta tendência à erosão das praias arenosas, nos dia de hoje, tem sido discutida por numerosos autores e a maioria deles tem admitido que a subida do nivel relativo do mar em curso seria a causa mais importante do fenômeno. Bruun \& Schwartz (1985) estimaram que, conforme a região considerada, a ascensão do nível relativo do mar estaria contribuindo com $10 \mathrm{a}$ $100 \%$ na erosão praial.

As dunas eólicas, as praias arenosas e as zonas costeiras adjacentes atuam como "verdadeiros amortecedores" da energia das ondas sendo, portanto essenciais na proteção do continente contra a erosão marinha. Conse- qüentemente, elas constituem ambientes sedimentares extremamente dinâmicos e sensíveis a mudanças em escalas temporais variáveis entre poucos segundos a vários anos (Fig. 21).

As relações de causa e efeito dos processos de erosão costeira têm sido exaustivamente discutidas na literatura. Komar (1983) sugeriu que a erosão costeira seria resultante de uma complexa interação de processos físicos, bem como de movimentos combinados das águas induzidos pelas ondas incidentes, marés, vagas de tempestade e correntes litorâneas. Short (1979), Wright et al. (1979) e Short \& Hesp (1982) sugeriram que os estados morfodinâmicos das praias e das zonas de surfe são também outros fatores importantes nos processos erosivos de escala local e de curta duração.

Bruun \& Schwartz (1985) apresentam a seguinte lista de sete fatores que seriam atuantes na erosão praial:

a) efeitos do impacto humano, através da construção de estruturas artificiais, mineração de areia praial, dragagem em zona costa afora, construção de barragens em rios (efeito represamento);

b) perda de sedimentos para zonas costa afora (plataforma continental), costa adentro (dunas eólicas), por deriva litorânea ao longo da costa e por desgaste devido ao atrito dos grãos entre si;

c) redução no suprimento sedimentar originário do fundo oceânico adjacente; 
Figura 21. Terraços marinhos arenosos formados no Holoceno, com uma laguna na sua porção mais interna, apresentando evidências de recuo da praia por perda de areia para duna $(A)$, para a plataforma continental (C) ou por deriva litorânea (B). Naturalmente, dois ou mais desses processos podem atuar simultaneamente (Bird, 1981).

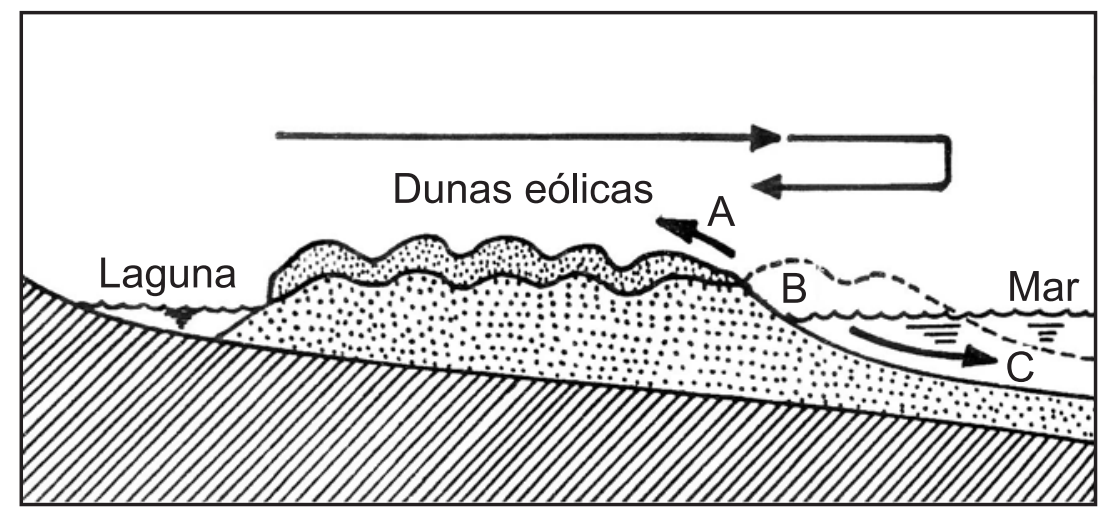

d) redução no suprimento sedimentar devida à desaceleração na erosão de falésias marinhas;

e) intensificação da "tempestuosidade" (storminess) na área costeira ou mudanças no ângulo de incidência das ondas;

f) aumento do grau de saturação em água das praias devido à subida do lençol freático ou pelo incremento de pluviosidade;

g) subida do nível relativo do mar.
Além dos autores supracitados, para Bird (1986) e Carter (1988), a erosão praial resulta de vários mecanismos causais, tais como ascensão do nível relativo do mar, instabilidade tectônica, subsidência e soerguimento isostático, mudanças climáticas (com particular influência da "tempestuosidade"), além dos efeitos antrópicos (Fig. 22).

Não é nada fácil determinar o papel desempenhado por cada um desses fatores no balanço sedimentar. Estudos regionais em amplas áreas são necessários para a

Fontes de sedimentos

Carga fluvial

Erosão costeira (ex. falésia)

Transporte costa adentro

Processo eólico

\section{Sumidouros de sedimentos}

Acreção costeira

$\frac{\text { L }}{\mathrm{N}}$ Lavagem por tempestade

Estrutura costeira

Processo eólico

Transporte costa afora

Extração de água subt. ou outro fluido Desenvolvimento de bacia hidrográfica

$\frac{\omega}{\bar{T}}$ Dragagem para manutenção

Manutenção de praia (extração de areia)

Estrutura costeira (espigão, quebramar)

Danificação de dunas eólicas

Construção de rodovias

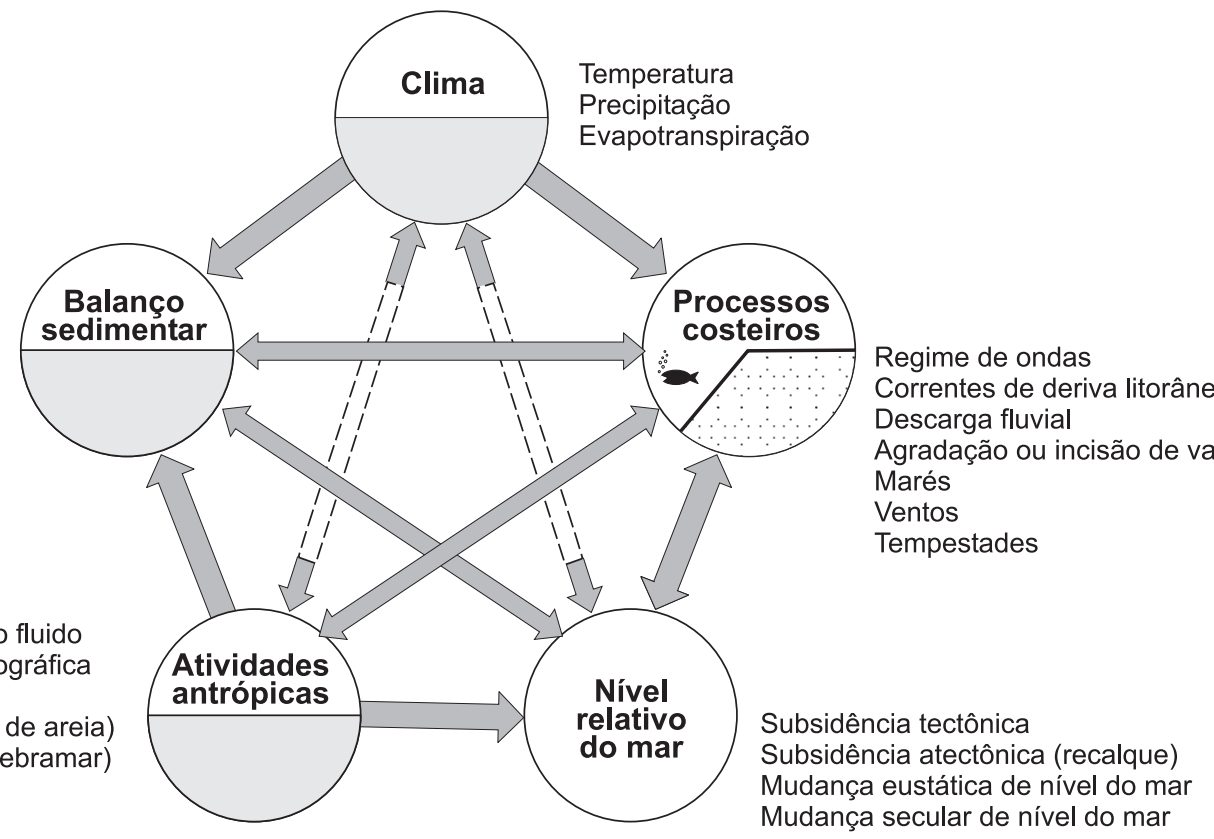

Construção de barragens (efeito represamento)

Figura 22. Diagrama representando alguns dos principais fatores que intervém na dinâmica sedimentar de uma praia e as suas complexas inter-relações (baseado em Pilkey et al., 1989). 
compreensão das contribuições relativas dos diferentes processos, ao longo da costa, para tentar mitigar os efeitos da erosão e promover a conservação de praias em um programa de gerenciamento costeiro.

\section{III.5. Conservação de ecossistemas costeiros}

Além das praias arenosas e paredões rochosos, que também constituem importantes ecossistemas costeiros, no Brasil devem ser enfatizados os ecossistemas de manguezal e recifes de corais.

Recentemente, Schaeffer-Novelli \& Cintrón-Molero (1999) discutiram aspectos da ecologia histórica dos manguezais brasileiros. Desde muito antes da descoberta do Brasil, há mais de 5.000 anos, os manguezais já existiam e constituíam uma importante fonte de recursos naturais, principalmente alimentares, para o Homem do sambaqui. Porém, após a descoberta do Brasil pelos portugueses, durante os últimos 500 anos, os manguezais passaram a fornecer madeiras para a lenha, produção de carvão e extração de tanino, além de servir de sítio para pesca e coleta de moluscos e crustáceos, ao lado da produção de sal. Hoje em dia são relativamente freqüentes as áreas, ao longo do litoral brasileiro, em que os manguezais foram simplesmente aterrados para serem ocupadas por bairros residenciais, sistemas viários e "outras benfeitorias". Entretanto, o desenvolvimento sustentável, com inteira garantia de conservação das regiões litorâneas, nunca deveria ser implementado ignorando-se a importância ecológica dos manguezais. Para isso, tornam-se necessários melhores conhecimentos não somente da ecologia, bem como das diversidades biológica e funcional deste ecossistema. Portanto, segundo os autores supracitados, as perspectivas históricas estariam indicando a urgente necessidade de conservação, manejo e restauração dos manguezais, principalmente daqueles mais próximos aos maiores centros urbanos, onde se encontram fortemente degradados e, desta maneira, ameaçados de extinção.

Por outro lado, conforme Leão \& Kikuchi (1999), os recifes de corais, muito bem representados no litoral da Bahia, evoluíram como os manguezais, durante os últimos milênios, inicialmente com influência antrópica desprezível. Segundo os estudos desses autores, a história evolutiva dos recifes de corais nas regiões litorâneas brasileiras iniciou-se há mais de 7.000 anos, concomitantemente à propagação deste ecossistema em outras regiões tropicais do mundo. Presentemente, os re- cifes de corais encontram-se submetidos aos efeitos danosos de diversas atividades humanas. A sua sobrevivência depende, no entanto, da melhor compreensão dos processos evolutivos, que deverão subsidiar a implementação de programas de conservação e manejo, visando o desenvolvimento sustentável, sem prejudicar a sobrevivência dos animais e vegetais que integram este importante ecossistema.

\section{AGRADECIMENTOS}

Especiais agradecimentos do autor a Sra. Thelma Samara pelo tratamento digital das ilustrações e a Sra. Nanci Iurico Assakura pelo trabalho de editoração.

\section{REFERÊNCIAS BIBLIOGRÁFICAS}

ACIESP - Academia de Ciências do Estado de São Paulo (1987) Anais do I Simpósio sobre ecossistemas da costa sul e sudeste brasileira. Publ. ACIESP n 54-I:459 p.; 54-II:425 p.; 54-III:363 p., São Paulo.

ACIESP (Academia de Ciências do Estado de São Paulo), (1990) Anais do II Simpósio sobre ecossistemas da costa sul e sudeste brasileira. Publ. ACIESP no 71-1:448 p.; 71-2:432 p.; 71-3:498 p., São Paulo.

ACIESP (Academia de Ciências do Estado de São Paulo) / (Academia Brasileira de Ciências), (1994) Anais do III Simpósio de ecossistemas da costa brasileira: subsídios a um gerenciamento ambiental. Publ. ACIESP nº 87- I:452 p.; 87- II:323 p.; 87- III:358 p., São Paulo.

ACIESP (Academia de Ciências do Estado de São Paulo) / ABC (Academia Brasileira de Ciências), 1998. Anais do IV Simpósio de ecossistemas brasileiros. Publ. ACIESP n ${ }^{\circ} 104-I: 399$ p.; 104-II:451 p.;104-III:442 p.; 104-IV:294 p.; 104-V:299p.

ALHEIROS, M. M. (1995) Riscos geológicos na zona costeira da região metropolitana de Recife. Salvador. 42 p. (Projeto de tese - doutorado) - Instituto de Geociências - Universidade Federal da Bahia.

ANGUlO, R. J.; GIANNINI, P. C. F.; SUGUIO, K.; PESSENDA, L. C. R. (1999) Relative sea-level changes in the last 5,500 years in southern Brazil (LagunaImbituba region, Santa Catarina State) based on vermemetid ${ }^{14} \mathrm{C}$ ages. Marine Geologie, v. 159, p. 323-339. 
BACCOCOLI, G. (1971) Os deltas marinhos holocênicos brasileiros. Uma tentativa de classificação. Boletim Técnico Petrobrás, v. 14, p. 5-38.

BARBOSA, L. M.; BITTENCOURT, A. C. S. P.; DOMINGUEZ, J. M. L.; MARTIN, L. (1987) The Quaternary coastal deposits of the State of Alagoas: Influence of relative sea-level changes. Quaternary of South America and Antarctic Peninsula, v. 4, p. $269-290$

BERNAT, M.; MARTIN, L.; BITTENCOURT, A. C. S. P.; VILAS-BOAS, G. S. (1983) Datation Io/U du plus haut niveau marin interglaciaire sur la côte du Brésil. Utilisation $\mathrm{du}^{229} \mathrm{Tr}$ comme traceur. Comptes Rendus de l'Academie de Sciences de Paris, v. 296, p.197-200.

BIGARELLA, J. J.;ANDRADE, G. O. (1964) Considerações sobre a estratigrafia dos sedimentos cenozóicos em Pernambuco (Grupo Barreiras). Arquivos do Instituto de Ciências da Terra, v. 2, p. 2-14.

BIRD, E. C. F. (1981) Recente changes on the world's sandy shorelines. In:.BIRD, E. C. F.; KOIKE, K. (eds.) Coastal dynamics and scientific sites. Tokyo, Dept. of Geography-Komazawa University, p. 5-30.

BIRD, E. C. F. (1985) Coastline changes: a global review. Londres, John Wiley \& Sons, 219 p.

BIRD, E. C. F. (1986) Potential effects of sea-level rise on the coast of Australia, Africa and Asia. In: TITUS, J. G. (ed.) Effects of changes in stratospheric ozone and global change. Washington, U. S. Environmental Protection Agency, v. 4.

BITTENCOURT,A. C. S. P.; MARTIN, L.; VILAS-BOAS, G. S.; FLEXOR, J. M. (1979) The marine formations of the coast of the State of Bahia, Brazil. In: SUGUIO, K.; FAIRCHILD, T. R.; FLEXOR, J. M. (eds.) International Symposium on Coastal Evolution in the Quaternary, São Paulo, 1979. Proceedings. São Paulo, Instituto de Geociências, p. 232-253.

BITTENCOURT, A. C. S. P.; DOMINGUEZ, J. M. L.; MARTIN, L.; FERREIRA, Y. A. (1982) Evolução do "delta" do Rio São Francisco (SE-AL) durante o Quaternário: Influência das variações do nível relativo do mar. In: SUGUIO, K.; MÉIS, M.R.M.; TESSLER, M.G. (eds) Simpósio do Quaternário no Brasil, 4., Rio de Janeiro, 1982. Atas. Rio de Janeiro, CenpesPetrobras, p. 46-68.

BLOOM, A. L. (1965) The explanatory description of coasts. Zeitschrift für Geomorphologie. v. 9, p. 422-436.

BLOOM, A. L.; BROECKER, W. S.; CHAPPELL, J. M. A.; MATTHEWS, R. K.; MESOLELLA, K. J. (1974) Qua- ternary sea-level fluctuations on a tectonic coast: New ${ }^{238} \mathrm{Th}^{234} \mathrm{U}$ dates from the Huon Peninsula, New Guinea. Quaternary. Research., v. 4, n. 2, p. 185-205.

BRANNER, J. C. (1904) The stone reefs of Brazil, their geological and geographical relations. Bulletin of the $\mathrm{Mu}$ seum of Comparative Zoology. Geological Series, v. 44, p. 207-275.

BRUUN, P. (1962) Sea-level rise as a cause of shore erosion. Proceedings of the American Society of Civil Engineers, v. 88, p.117-130.

BRUUN, P.; SCHWARTZ, M. L. (1985) Analytical predictions of beach profile change in response to sea-level rise. Zeitschrift für Geomorphologie, v. 57, p. 33-50.

CARTER, R. W. G. (1988) Coastal environments: an introducton to the physical, ecological and cultural systems of coastlines. London, Academic Press: $617 \mathrm{p}$.

CHAPPELL, J. M. A. (1983) A. revised sea-level records of the last 300,000 years from Papua-New Guinea. Search, v. 14, p. 99-104.

COLEMAN, J. M.; WRIGHT, L. D. (1975) Modern river deltas: Variability of process and sand bodies. In: BROUSSARD, M. L. (ed.) Delta-models for exploration. Texas, Houston Geological Society, p. 99-149.

CORRÊA, I. C. S. (1979) Paleolinhas de costa na plataforma continental entre São Paulo e Santa Catarina. In: SIMPÓSIO REGIONAL DE GEOLOGIA, 2., Rio Claro, 1979. Atas. Rio Claro, SBG. v. 1, p. 269-278.

CORREAA, I. C. S. (1990) Analyse morphostructurale et évolution paléogéographique de la plate-forme continentale Atlantique Sud Brésilienne (Rio Grande do Sul, Brésil). Bordeaux, 314 p. (Thèse-Doctorat) - Univ. de Bordeaux.

CORRÊA, I. C. S. (1996) Les variations du niveau de la mer durant les derniers 17500 ans BP: 1'exemple de la plate-forme continentale du Rio Grande do Sul, Brésil. Marine Geology, v. 130, p. 163-178.

DELGADO DE CARVALHO, C. M. (1927) Fisiografia do Brasil. Rio de Janeiro.

DOMINGUEZ, J. M. L. (1982) Evolução quaternária da planície costeira associada à foz do Rio Jequitinhonha (BA): Influência das variações do nível do mar e da deriva litorânea de sedimentos. Salvador, 79 p. (Dissertação - Mestrado) - Instituto de Geociências - UFBA.

DOMINGUEZ, J. M. L.; BITTENCOURT, A. C. S. P.; MARTIN, L. (1981) Esquema evolutivo da sedimentação quaternária nas feições deltaicas dos rios São 
Francisco (SE-AL), Jequitinhonha (BA), Doce (ES) e Paraíba do Sul (RJ). Revista Brasileira Geociências, v. 11, p. 225-237.

DOMINGUEZ, J. M. L.; MARTIN, L.; BITTENCOURT, A. C. S. P. (1987) Sea-level history and Quaternary evolution of river mouth associated beach-ridge plains along the eastern-southeastern Brazilian coast: a summary. In: NUMMEDAL, D.; H.PILKEY, O.; HOWARD, I. D. (eds.) Sea-level fluctuation and coastal evolution. Tulsa, Society of Economic Paleontologists and Mineralogists, p. 115-127. (Special Publication. Society of Economic Paleontologists and Mineralogists, 41)

DOMINGUEZ, J. M. L.; BITTENCOURT,A. C. S. P.; LEÃO, Z. M.A. N.; AZEVEDO, A. E. G. (1990) Geologia do Quaternário Costeiro do Estado de Pernambuco. Revista Brasileira de Geociências , v. 20, p. 208-215.

FAIRBRIDGE, R. W. (1961) Eustatic changes in sea level. In: FAIRBRIDGE, R. W. Physics and chemistry of the Earth. New York, Pergamon Press, v. 4.

FAIRBRIDGE, R. W. (1976) Shellfish-eating preceramic indians in coastal Brazil. Science, v. 191, n. 4225, p. 353-359.

FISHER, W. L. (1969) Facies characterization of coast basin delta system, with Holocene analogues. Transactions GulfCoast Association of. Geological Societes, n. 19, p. 239-261.

FLEXOR, J. M. ; MARTIN, L. (1979) Sur l'utilisation des grès coquilliers de la région de Salvador (Brésil) dans la reconstruction des lignes de rivages holocènes. In: SUGUIO, K.; FAIRCHILD, T. R.; FLEXOR, J. M. (eds.) INTERNATIONAL SYMPOSIUMON COASTAL EVOLUTION IN THE QUATERNARY, São Paulo, 1979. Proceedings. São Paulo, Instituto de Geociências, p. 343-355.

FRANCO, L. (1993) Nuove tecnologie per la difesa dei litorali. In: AMINTI, P.; PRANZINI, E. (eds.) La difesa dei litorali in Italia. Roma, Edizioni delle Autonomie, p. 25-49.

FRANZINELLI, E. (1982) Contribuição à geologia da costa do Estado do Pará (entre Baía de Curuçá e Maiaú). In: SUGUIO, K.; MÉIS, M. R. M.; TESSLER, M. G. (eds) Simpósio do Quaternário no Brasil, 4., Rio de Janeiro, 1982. Atas. Rio de Janeiro, Cenpes-Petrobras, p. 305-322.

GALLOWAY, W. E. (1975) Process framework for describing the morphologic and stratigraphe evolution of deltaic depositional systems. In: BROUSSARD, M.L. (ed.) Delta-models for exploration. Houston, Geo- logical Society Houston, p. 87-89.

GIBBS, R. J. (1976) Amazon river sediment transport in the Atlantic ocean. Geology, v. 4, p. 45-48.

HAYES, M. O.(1979) Barrier island morphology as a function of tidal and wave regime. In: LEATHERMAN, S.P. (ed.) Barrier islands from Gulf of Saint Lawrence to the Gulf of Mexico. Nova York, Academic Press, p. 1-27.

HOYT, J. H. (1967) Barrier-island formation. Geological Society America Bullettin, v. 79, p. 91-94.

HOYT, J. H. (1969) Chenier versus barrier, genetic and stratigraphic distinction. AAPG Bulletin, v.53, n.2, p. 299-306.

JOHNSON, D. W. (1919) Shore processes and shoreline development. John Wiley \& Sons, $584 \mathrm{p}$.

KING, C. A. M. (1972) Beaches and coasts. $2^{\mathrm{a}}$ ed. Londres, Edward Arnold, $570 \mathrm{p}$.

KOIKE, K. (1996) The countermeasures against coastal hazards in Japan. GeoJournal, v. 38, n. 3, p. 301-312.

KOIKE, K. (1997) Como harmonizar-se com o litoral. Maneiras de harmonizar-se com os ambientes naturais, Série $\mathrm{n}^{\mathrm{o}}$ 5. Iwanami-shoten, 131 p. (em japonês).

KOMAR, P. D. (1983) Handbook of coastal processes and erosion. Boca Raton, CRC Press, 297 p.

KOUSKY, V. E.; KAGANO, M. T.; CAVALCANTE, I. F. A. (1984) A review of Southern Oscillation: oceanic-atmospheric circulation changes and related rainfall anomalies. Tellus, v. 36A., p. 490-504.

KOWSMANN, R. O.; COSTA, M. P. A.; VICALVI, M. A.; COUTINHO, M. G. N.; GAMBOA, L. A. P. (1977) Modelo de sedimentação holocênica na plataforma continental sul brasileira. In: Projeto REMAC: Evolução sedimentar holocênica da plataforma continental e do talude do sul do Brasil. Rio de Janeiro, Petrobrás/ CENPES, 2:7-26 (Série Projeto REMAC, 2).

LABOREL, J. (1979) Fixed marine organisms as biological indicators for the study of recent sea-level and climatic variations along the Brazilian tropical coast. In: SUGUIO, K.; FAIRCHILD, T. R.; FLEXOR, J. M (eds.) INTERNATIONAL SYMPOSIUMON COASTAL EVOLUTION IN THE QUATERNARY, São Paulo, 1979. Proceedings. São Paulo, Instituto de Geociências, p. 193-211.

LEÃO, Z. M. A. N.; KIKUCHI, R. K. (1999) The Bahian coral reefs - from 7,000 years BP to 2,000 years AD. Journal Brazilian Association Advancement Science, v. 13, p. 262-273.

LOWE, J. J.; WALKER, M. J. C. (1997) Reconstructing 
Quaternary Environments. Londres, Longman, $446 \mathrm{p}$.

MARTIN, L.; SUGUIO, K. (1992) Variation of coastal dynamics during the last 7,000 years recorded in beachridge plains associated with river mouths: example from the Central Brazilian coast. Palaeogeography, Palaeoclimatology, Palaeoecology, v. 99, p.119-140.

MARTIN, L.; SUGUIO, K.; FLEXOR, J. M.; DOMINGUEZ, J. M. L.;AZEVEDO,A. E. G. (1984a) Evolução da planície costeira do Rio Paraíba do Sul (RJ) durante o Quaternário: influência das flutuações do nível do mar. In: CONGRESSOBRASILEIRODE GEOLOGIA, 33., Rio de Janeiro, 1984. Anais. Rio de Janeiro, SBG, v. 1, p. 84-97.

MARTIN, L.; FLEXOR, J. M.; KOUSKY, V. E.; CAVALCANTI, J. F. A. (1984b) Inversion du sens du transport littoral enrégistrées dans les cordons littoraux de la plaine côtière du Rio Doce (Brésil). Possible liaison avec des modifications de la circulation atmosphèrique. Comptes Rendus de l'Académie de Sciences de Paris, T. 298, Série II, p. 25-27.

MARTIN, L.; MÖRNER, N. A.; FLEXOR, J. M.; SUGUIO, K. (1986a) Fundamentos e reconstrução de antigos níveis marinhos do Quaternário. Boletim IG-USP. Publicação Especial, v. 4, p. 1-161.

MARTIN, L.; SUGUIO, K.; FLEXOR, J. M. (1986b) Shellmiddens as a source for additional information in Holocene shoreline and sea-level reconstruction: Examples from the coast of Brazil. In: VAN DE PLASSCHE, O. (ed.) Sea-level research: a manual for collection and evaluation of data. Norwich, Geobooks, p. 503-521.

MARTIN, L.; SUGUIO, K.; FLEXOR, J. M.; DOMINGUEZ, J. M. L.; BITTENCOURT, A. C. S. P. (1987a) Quaternary evolution of the central part of the Brazilian coast. The role of relative sea-level variation and of shoreline drift. UNESCO Technical Papers in Marine Science, v. 43, p. 97-145.

MARTIN, L.; SUGUIO, K.; FLEXOR, J. M. (1987b) Relative sea-level reconstruction during the last 7,000 years along the states of Paraná and Santa Catarina: additional informations derived from shell-middens. Quaternary of South America and Antarctic Peninsula, v. 4, p. 219-236.

MARTIN, L.; SUGUIO, K.; FLEXOR, J. M.; AZEVEDO,A. E. G. (1988a.) Mapa geológico do Quaternário costeiro dos estados de Paraná e Santa Catarina. Brasília, DNPM, 40p. Série Geologia n 28./Geologia
Básica ${ }^{\circ}$ 18. (Escala: 1:250.000)

MARTIN, L.; SUGUIO, K.; FLEXOR, J. M. (1988b) Hauts niveaux marins pléistocènes du littoral brésilien. Palaeogeography, Palaeoclimatology, Palaeoecology, v. 68, p. 231-238.

MARTIN, L.; SUGUIO, K.; FLEXOR, J. M. (1993) As flutuações do nível do mar durante o Quaternário superior e a evolução geológica de "deltas" brasileiros. Boletim IG-USP, Publicação Especial, v. 15, p. 1-186.

MARTIN, L.; SUGUIO, K.; FLEXOR, J. M.; DOMINGUEZ, J. M. L.; BITTENCOURT, A. C. S. P. (1996) Quaternary sea-level history and variations in dynamics along the Central Brazilian coast: consequences on coastal plain construction. Anais da Academia Brasileira de Ciências, v. 68, p. 303-354.

MARTIN, L.; SUGUIO, K.; DOMINGUEZ, J. M. L.; FLEXOR, J. M. (1997) Geologia do Quaternário Costeiro do litoral norte do Rio de Janeiro e do Espírito Santo. São Paulo, FAPESP/CPRM. (Escala 1:200.000 e texto explicativo).

MARTIN, L.; BITTENCOURT, A. C. S. P.; DOMINGUEZ, J. M. L. (1999) Physical setting of the Discovery Coast: Porto Seguro region (Bahia). Journal Brazilian Association Advancement Science, v. 51, p. 245-261.

MASSAD, F.; SUGUIO, K.; PÉREZ, F. S. (1996) Propriedade geotécnica de sedimentos argilosos como evidência de variações do nível relativo do mar em Santos. In: CONGRESSO BRASILEIRO DE GEOLOGIA DE ENGENHARIA, 8., Rio de Janeiro, 1996. Anais. Rio de Janeiro, ABGE, v. 1, p. 163-176.

MESQUITA, A. R. (1994) Variações no nível do mar nas costas brasileiras. Afro-American Gloss News, v.1, p. 3-4.

NITTROUER, C. A.; KUEHL, S. A.; DEMASTER, D. J.; KOWSMANN, R. O. (1986) The deltaic nature of Amazon shelf sedimentation. Geological Society of America Bullettin, v. 97, n. 4, p. 444-458.

PECK, D. L.; WILLIAMS, S. J. (1992) Sea-level rise and its implications in coastal planning and management. In: FABRI, P. (ed.) International Conference on Ocean Management in Global Change. Elsevier Applied Science, p. 57-73.

PIGB (Programa Internacional Geosfera-Biosfera), (1990) Programa Internacional Geosfera-Biosfera: Um estudo de mudança global. Os projetos núcleos inicias. Capítulo 4: Como as mudanças no uso da Terra afetam os recursos da zona costeira e como as mudanças no nível do mar e do clima alteram os ecossistemas cos- 
teiros, Estocolmo, PIGB. (Relatório $\mathrm{n}^{\mathrm{o}} 12$ ).

PILKEY,O.H.; MORTON, R.A.; KELLEY, J.T.; PENLAND, S. (1989) Coastal land loss. Washington, American Geophysics Union, 73 p.

PRICE, W. (1955) Environment and formation of the chenier plain. Quaternaria, v. 2, p. 75-86.

RAJA GABAGLIA, F. A. (1916) As fronteiras do Brasil. Rio de Janeiro, Jornal do Comércio, 78 p.

RODRIGUES, S. A. (1966) Estudos sobre Callianassa. São Paulo, 168p. (Tese - Doutorado) - Faculdade de Filosofia Ciências e Letras,-Universidade de São Paulo.

RUSSELL, R. J. (1958) Geological geomorphology. Geological Society America Bulletin, v. 69, p. 1-22.

RUSSELL, R. J. (1967) River plains and sea coasts. Berkeley, University Califonia Press.

SCHAEFFER-NOVELLI, Y.; CINTRÓN-MOLERO, G.(1999) Brazilian mangroves: a. historical ecology. Journal Brazilian Association Advancement Science, 13:274-286.

SCHAEFFER-NOVELLI, Y; CINTRÓN-MOLERO, G.; ADAIME, R. R.; CAMARGO, T. M. (1990) Variability of mangrove ecosystems along the Brazilian coast. Estuaries, v. 13, p. 204-219.

SHEPARD, F. P. (1963) Submarine Geology. $2^{\mathrm{a}}$ ed. Nova York, Harper and Row, 557 p.

SHORT, A. D. (1979) Three dimensional beach-ridge model. Journal of Geology, v. 87, p. 553-571.

SHORT, A. D.; HESP, P. A. (1982) Wave, beach and dune interactions in southern Australia. Marine Geology, v. 48, p.105-140.

SILVEIRA, J. D. (1964) Morfologia do litoral. In: AZEVEDO, A. (ed.) Brasil: a terra e o homem. São Paulo, Cia. Editora Nacional, p. 253-305.

SOUZA, C.R.G.; SUGUIO, K. (1996) Coastal erosion and beach morphodynamics along the State of São Paulo (SE Brazil). Anais da Academia Brasileira de Ciências, v. 68, p. 405-424.

SOUZA FILHO, P. W. M. (1995) Influência das variações do nível do mar na morfoestratigrafia da planície costeira Bragantina (NE do Pará) durante o Holoceno. Belém, 123p. (Dissertação - Mestrado) Centro de Geociências / UFPA.

SOUZA FILHO, P. W. M.; EL-ROBRINI, M. (1997) A influência das variações do nível do mar na sedimentação da planície Bragantina durante o Holoceno. In: COSTA, M. L. DA; ANGÉLICA, R. S. (eds.) Contribuição à geologia da Amazônia. Belém, FINEP/SBG-Núcleo Norte, p. 307-337.
SUGUIO, K. 1999. Geosciences and commemoration of Brazil's 500-year anniversary of discovery. Journal Brazilian Association Advancement Science, 51:235.

SUGUIO, K.; MARTIN, L. (1976) Presença de tubos fósseis de Callianassa nas formações quaternárias do litoral paulista e sua utilização na reconstrução paleoambiental. Boletim IG-USP. Série Cientifica, v. 7, p. 17-26.

SUGUIO, K.; MARTIN, L. (1978) Quaternary marine formations of the states of São Paulo and southern Rio de Janeiro. In: INTERNATIONAL SYMPOSIUM ON COASTAL EVOLUTION INTHEQUATERNARY. São Paulo. Special Publication. São Paulo, Brazilian National Working Group for the IGCP-Project 61, n.1, p. $1-55$ p.

SUGUIO, K.; MARTIN, L.; DOMINGUEZ, J. M. L. (1982) Evolução da planície costeira do Rio Doce (ES) durante o Quaternário: Influência das flutuações do nível do mar. In: SUGUIO, K.; MÉIS, M. R. M.; TESSLER, M. G. (eds) Simpósio do Quaternário no Brasil, 4., Rio de Janeiro, 1982. Atas. Rio de Janeiro, Cenpes-Petrobras, p. 93-116.

SUGUIO, K.; MARTIN, L.; DOMINGUEZ, J. M. L.; BITTENCOURT, A. C. S. P.; FLEXOR, J. M. (1984) Quaternary emergent and submergent coasts: Comparison of the Holocene sedimentation in Brazil and southeastern United States. Anais da Academia Brasileira de Ciências, v. 56, p.163-167.

SUGUIO, K.; MARTIN, L.; BITTENCOURT, A. C. S. P.; DOMINGUEZ, J. M. L.; FLEXOR, J. M.; AZEVEDO, A. E. G. (1985 a) Flutuações do nível relativo do mar durante o Quaternário superior ao longo do litoral brasileiro e suas implicações na sedimentação costeira. Revista Brasileira de Geociências, v. 15, p. 273-286.

SUGUIO, K.; MARTIN, L.; FLEXOR, J. M.; TESSLER, M. G.; EICHLER, B. B. (1985b) Depositional mechanisms active during the late Quaternary at the Paraíba do Sul river mouth area, State of Rio de Janeiro. Brazil. Quaternary of South America and Antarctic Peninsula, v. 3, p. 175-185.

SUGUIO, K.; MARTIN, L.; FLEXOR, J. M. (1992) Paleoshorelines and the sambaquis of Brazil. In: JOHNSON, L. L.; STRIGHT, M. (eds.) Paleoshorelines and Prehistory: an investigation of method. Boca Raton, CRC Press, p. 83-99.

SUGUIO, K.; FORNERIS, L.; SCHAEFFER-NOVELLI, Y. (1996) Proceedings of the LOICZ (Land-Ocean Interactions in the Coastal Zone) Scientific meeting. Anais 
da Academia Brasileira de Ciências, v. 68, p. 303-508.

SUGUIO, K.; DOMINGUEZ, J. M. L.; LESSA, G. C.; SOUZA, C. R. G.; TOMAZELLI, L. J.; VILLWOCK, J. A. (eds.) (1998) Proceedings of the LOICZ (Land-Ocean Interactions in the Coastal Zone) Symposium. Anais da Academia Brasileira de Ciências, v. 70, p. 159-374.

TANNER, W. F. (1960) Bases of coastal classification. Southeastern Geology, v. 2, p.13-22.

TOMAZELLI, L. J.; VILLWOCK, J. A.; DILLENBURG, S. R.; BACHI, F. A.; DEHNHARDT, B. A. (1998) Significance of present-day coastal erosion and marine transgression, Rio Grande do Sul, southern Brazil. Anais da Academia Brasileira de Ciências, v. 70, p. 221-229.

VALENTIN, H. (1952) Die Küsten der Erde. Justus Perthes Gotha, $118 \mathrm{p}$.

VILLWOCK, J. A.; TOMAZELLI, L. J.; LOSS, E. L.; DEHNHARDT, E. A.; HORN FILHO, N. O.; BACHI, F. A.; DEHNHARDT, B. A. (1986) Geology of the Rio Grande do Sul coastal province. Quaternary of South America and Antarctic Peninsula, v. 4, p. 79-97.

WRIGHT, L. D.; CHAPPELL, J. M. A.; THOM, B. G.; BRADSHAW, M. P.; COWELL, P. (1979) Morphodynamics of reflective and dissipative beach and inshore systems: southern Australia. Marine Geology, v. 32, p. 105-140.

\section{BIBLIOGRAFIA ADICIONAL PARA EVENTUAL CONSULTA}

SUGUIO, K. (1992) Dicionário de Geologia Marinha (com termos correspondentes em inglês, francês e espanhol). São Paulo, T. A. Queiroz, 171 p.

SUGUIO, K. (1998) Dicionário de Geologia Sedimentar e Áreas Afins (com termos correspondentes em inglês, francês, espanhol e alemão). Rio de Janeiro, BertrandBrasil, $1217 \mathrm{p}$.

SUGUIO, K. (1999) Geologia do Quaternário e Mudanças Ambientais (Passado + Presente = Futuro?). São Paulo, Paulo's Editora, 366 p. 